\title{
Influence of OSHV-1 oyster mortality episode on dissolved inorganic fluxes: An ex situ experiment at the individual scale
}

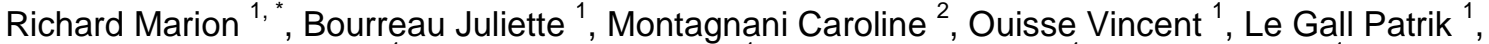 \\ Fortune Martine ${ }^{1}$, Munaron Dominique ${ }^{1}$, Messiaen Gregory ${ }^{1}$, Callier Myriam ${ }^{1}$, \\ Roque D'Orbcastel Emmanuelle
}

\footnotetext{
1 Ifremer, MARBEC UMR 9190 (IRD, Ifremer, UM, CNRS), Avenue Jean Monnet, 34203 Sète, France

2 Ifremer, IHPE UMR 5244 (Univ. Perpignan Via Domitia, CNRS, Univ. Montpellier), 34095 Montpellier, France
}

*Corresponding author : Marion Richard, email address : marion.richard@ifremer.fr

\begin{abstract}
:
Ostreid herpesvirus 1 (OsHV-1 $\mu$ var) infection has caused significant mortalities in juvenile oysters (Crassostrea gigas). In contrast to the practices of other animal production industries, sick and dead oysters are not separated from live ones and are left to decay in the surrounding environment, with unknown consequences on fluxes of dissolved materials. A laboratory approach was used in this study to test the influence of oyster mortality episode on dissolved inorganic fluxes at the oyster interface, dissociating (i) the effect of viral infection on metabolism of juvenile oysters and (ii) the effect of flesh decomposition on oxygen consumption and nutrient releases at the individual scale. Nine batches of juvenile oysters (Individual Total wet weight $1 \mathrm{~g}$ ) were infected via injection of OsHV-1 enriched inoculums at different viral loads (108 and 109 OsHV-1 DNA copies per oyster) to explore infection thresholds. Oysters injected with filtered seawater were used as controls (C). Oysters were maintained under standard conditions to avoid stress linked to hypoxia, starvation, or ammonia excess. Before, after the injection and during the mortality episode, i.e. at days 1, 3, 7, 10 and 14, nine oysters per treatment were incubated in individual metabolic chambers to quantify oxygen, ammonium and phosphate fluxes at the seawater-oyster interface. Nine empty chambers served as a reference. Injections of the two viral loads of OsHV-1 induced similar mortality rates (38\%), beginning at day 3 and lasting until day 14. The observed mortality kinetics were slower than those reported in previous experimental pathology studies, but comparable to those observed in the field (Thau lagoon, France). This study highlights that oxygen and nutrient fluxes significantly varied during mortality episode. Indeed (i) OsHV-1 infection firstly modifies oyster metabolism, with significant decreases in oxygen consumption and ammonium excretion, and (ii) dead oysters lead to a strong increase of ammonium (6 fold) and phosphate (41 fold) fluxes and a decrease in the N/P ratio due to mineralisation of their flesh. The latter may modify the structure of the planktonic community in the field during mortality episode. This study is a first step of the MORTAFLUX program. The second step was to in situ confirm this abnormal nutrient loading during a mortality episode and show its impact on bacterio-, phyto- and protozoo-plankton.
\end{abstract}




\section{Highlights}

- This study is the first one to show consequences of oyster mortality episode in matter cycle using a lab approach Dissolved inorganic fluxes at the water-shell interface of Pacific oyster significantly varied during mortality episode - OsHV-1 infection decreases oxygen consumption and ammonium excretion of oyster juveniles. Mineralisation of the flesh of dead oysters leads to a profound increase in ammonium and phosphate fluxes and a decrease in the N/P ratio with potential incidence on planktonic communities.

Keywords : Crassostrea gigas, Mortality, Ostreid herpesvirus 1, Juvenile, Spat, Mineralisation, Oxygen consumption, Nutrient fluxes 


\section{Introduction}

Mortality episodes in cultured bivalves have been reported worldwide and have been associated with infection by a range of viral and bacterial pathogens (Barbosa Solomieu et al. 2015). Thus, the history of oyster culture consists of a succession of developmental phases using different species, followed by collapses caused by diseases as described in France (Buestel et al. 2009), where the indigenous species Ostrea edulis was replaced first with Crassostrea angulata in the 1920's, then C. gigas in the 1970s. First mortalities of the Pacific oyster, Crassostrea gigas in France, were reported in the early 1990s in hatcheries and nurseries, for larval and juvenile stages, and later in the field (Nicolas et al. 1992, Renault et al. 1994). These events have been primarily attributed to a herpes-like virus, based on histological and electron microscopy examinations (Renault et al. 1994, 2000) and PCR procedures (Le Deuff \& Renault 1999, Renault, Deuff, \& Delsert 2000). This herpes-like virus was later described and named ostreid herpesvirus 1 (OsHV-1) (Minson et al. 2000, Davison et al. 2005). Since 2008, a new variant, OsHV-1 $\mu$ var, has emerged (Segarra et al. 2010) and has induced abnormal juvenile mortality rates ranging from $80-100 \%$ along the French coast (Garcia et al. 2011). Mortality of oysters coincided with infections involving the ostreid herpes virus and also bacteria of the group Vibrio splendidus (Pernet et al. 2012, Petton, Bruto, et al. 2015). These oyster mortality episodes have caused important economic losses in France since 2008 (Girard and Pérez Agúndez 2014). The development of molecular tools has subsequently allowed the detection of these viruses in many countries in Europe, USA, Australia, New Zealand and in East Asia (Mineur et al. 2014 for review). In 2016, mortalities are still a key topic since they continue to occur each year in France at rates ranging from 35 to $70 \%$ (RESCO networks: http://wwz.ifremer.fr/observatoire_conchylicole). Thus mortality of Pacific oyster remain a huge problem, both from economic and scientific points of view in France and worldwide. 
The search for a better understanding of these phenomena and to address this crisis has led scientists to focus on the causes and consequences of viral infection on oyster juvenile. Some studies have described viral entry (Jouaux et al. 2013) and distribution in organs and tissues (Segarra et al. 2016); others have identified changes in immune ( Green et al. 2015, 2016, He et al. 2015, Moreau et al. 2015,), physiological and biochemical responses (Corporeau et al. 2014, Tamayo et al. 2014) in Pacific oyster spat infected with OsHV1. These studies have provided a better understanding of the interactions between OsHV-1 and oysters at the organism scale. In parallel, some studies have envisaged solutions by highlighting the factors controlling these mortality episodes, such as size, genetics (Dégremont 2013), energetic status (Pernet et al. 2010), husbandry practices (Paul-Pont et al. 2013, Pernet, Lagarde, Le Gall, et al. 2014, Whittington et al. 2015) and temperature (Pernet et al. 2012, Renault et al. 2014, Petton, Boudry, et al. 2015). However, to date, no studies have investigated the consequences of these mortality events in the environment, and especially on matter cycle.

Unlike in most other animal production industries, sick and dead individuals are not separated from conspecifics in shellfish farms, a practice that can favour cross-contamination and spread of disease. Dead oysters are kept in the rearing environment until their flesh totally disappears. The consequences of this practice for (i) the transfer of pathogens and (ii) particulate and dissolved fluxes into the environment remain unknown.

Apart from a mortality context, shellfish farms are known to modify the ecosystem functions of coastal environments. Indeed, shellfish modify particulate and dissolved fluxes via their (i) respiration (Chapelle et al. 2000, Richard et al. 2006), excretion (Mazouni 2004, Richard et al. 2007, Jansen et al. 2012, Lacoste and Gaertner-Mazouni 2016), (ii) filtration (Dupuy et al. 2000, Trottet et al. 2008) and (iii) biodeposition (Callier et al. 2006, 2009, Robert et al. 2013). At high stocking densities in confined environments, shellfish can control seston biomass via filtration (Smaal et al. 2013, Filgueira et al. 2014a, b), stimulate primary 
production via nitrogen excretion (Chapelle et al. 2000, Souchu et al. 2001, Mazouni 2004) and modify the microbial plankton community structure (Froján et al. 2014, Mostajir et al. 2015). Many studies have focused on this topic in adult organisms (see Cranford et al., 2003; McKindsey et al., 2006; Forrest et al., 2009; Filgueira et al., 2015 for reviews), but few data are available on the juvenile stage, either under laboratory treatments (Dame 1972, Goulletquer 1999) or in situ (Meseck et al. 2012, van Broekhoven et al. 2014). Filtration, respiration and excretion rates depend on organism size (see Gosling 2015a, b for reviews), so juveniles would not have the same influence on biogeochemical fluxes and planktonic communities as would be observed for adults. In the context of viral infection, the shellfish/environment interactions could be modified.

Diseases are known to decrease filtration (Newell 1985, Flye-Sainte-Marie et al. 2007), excretion and respiration rates (Flye-Sainte-Marie et al. 2007) of marine bivalves. In cases of mortality, oyster flesh probably decomposes and mineralises, thereby causing an increase of nutrients, as observed for mussels (Lomstein et al. 2006) and jellyfish (West et al. 2009). Increases in nutrient loading may in turn induce changes in planktonic components, but this possibility remains to be investigated in cases of oyster mortality. The aim of the MORTAFLUX project is to determine the influence of mortality episode of juvenile oyster on fluxes in the benthic-pelagic coupling of the Thau lagoon that corresponds to the most important French oyster culture site on the Mediterranean Sea.

In this paper, we present the first part of this project. The aim was to evaluate the influence of OSHV-1 mortality episode of oyster juveniles on the dissolved inorganic fluxes at the individual level, i.e. at the water-oyster shell interface, dissociating (i) the effect of viral infection on metabolism of oyster and (ii) the effect of flesh decomposition on oxygen demand and ammonium and phosphate releases at the individual scale. This first study was carried out under laboratory conditions, with the aim of inducing OsHV-1 infection by intramuscular injection of viral 
inoculum, as performed previously (Schikorski, Renault, et al. 2011), maintaining oysters in standard conditions used in ecophysiology to avoid any stress linked to stocking conditions (hypoxia, starvation, ammonia excess). Finally, recorded data of this first study will be up scaled from individual to the rearing structure to be further compared with in situ data issued from the second study of Mortaflux that was carried out before within and after a mortality episode in the Thau lagoon (France).

\section{Materials and methods}

\subsection{Site and equipment}

The experimental work was carried out at Ifremer's Aquaculture Research Facility at Palavas-les-Flots (France). Two rooms equipped with an effluent treatment system were dedicated to the pathology experiments. The first room contained a series of 24 similar aquaria $(\mathrm{W} \times \mathrm{L} \times \mathrm{H}: 35 \times 60 \times 30 \mathrm{~cm}) ; 12$ were filled with $60 \mathrm{~L}$ of filtered seawater and equipped with an air bubbler, a thermostat $\left(21^{\circ} \mathrm{C}\right)$, a foam filter and a water circulation system driven by an airlift and were used for acclimation of the oysters. The second room included three aquaria $(\mathrm{W} \times \mathrm{L} \times \mathrm{H}: 35 \times 60 \times 30 \mathrm{~cm})$, each equipped with a thermostat $\left(21^{\circ} \mathrm{C}\right)$ and an air bubbler, to be used for incubation experiments.

\subsection{Viral inoculum}

Viral inoculum was prepared as described by Schikorski et al. (2011b) using ten OsHV-1 laboratory-infected oyster juveniles. Briefly, the flesh was homogenised in 10 volumes of autoclaved seawater and this homogenate was clarified by centrifugation $(1000 \times \mathrm{g}$ for 10 $\left.\min , 4^{\circ} \mathrm{C}\right)$ before serial filtration $(8.0,0.45$ and $0.22 \mu \mathrm{m})$. This inoculum contained $2 \times 10^{7}$ C9/C10 DNA copies. $\mu \mathrm{L}^{-1}$ and was confirmed to be free of cultivable bacteria by plating $50 \mu \mathrm{L}$ of inoculum on Zobell marine and TCBS agar plates. Preliminary tests showed that a $50-\mu \mathrm{L}$ 
injection of this viral inoculum (i.e. $10^{9}$ DNA copies.oyster ${ }^{-1}$ ) induced in 4 days $67 \%$ mortality of oyster juvenile $(1 \mathrm{~g})$ that were confined at $22^{\circ} \mathrm{C}$ in a low water volume $(\mathrm{n}=15$, 15 ind. $5 \mathrm{~L}^{-1}: 3 \mathrm{~g} . \mathrm{L}^{-1}$ ) without a filtration system. This viral inoculum was 10 -fold diluted to obtain a second inoculum containing $2 \times 10^{6}$ copies. $\mu \mathrm{L}^{-1}$ to test the load effect on mortality kinetic and oyster metabolism. The two inoculums, called L1 and L2, were stored at $4{ }^{\circ} \mathrm{C}$ before injection during twelve days.

\subsection{Oysters, acclimation and experimental procedure}

A total of 370 juvenile diploid oysters were received on 3 March 2015 at Palavas. They had been produced and raised in the experimental hatchery of the Ifremer station in Argenton (Brittany, France), as described by Petton et al. (2015) and pre-grown in earthen ponds at the Ifremer station in Bouin (Vendée, France). Oyster spat production results from the reproduction of a large pool of broodstock sampled in the field. This material called "Naissain Standardized Ifremer" (NSI) is assumed to be "naïve", i.e. free of pathogens and not resistant to OSHV-1 pathogen. NSI are used as sentinel for the French shellfish observatory network (RESCO) and by several authors (Tamayo et al. 2014, Petton, Boudry, et al. 2015, Green et al. 2015). Upon receipt, the oysters were immediately randomly divided into three batches and acclimated for 1 week in three acclimation aquaria. One week after receipt, each batch was sub-divided into three groups of 38 individuals, which were randomly assigned to an infection treatment (C: control, L1, L2: infected by viral inoculum at the 2 viral loads) in preparation for injection. The oysters were then distributed at low density among nine aquaria (38 1gind.60 $\mathrm{L}^{-1}: 0.6 \mathrm{~g} \cdot \mathrm{L}^{-1}$ ) where they were kept until infection. During the acclimation and experiment periods, oysters were fed daily with Skeletonema sp. (supplied by SATMAR, Gatteville-Phare, France) with a ration equivalent to $5 \%$ of the oyster dry weight, to avoid potential starvation stress. Temperature and salinity were measured every day using a WTWLF197S probe. The mean ( \pm Standard Error: SE) temperature was $20.8 \pm 0.96^{\circ} \mathrm{C}$ and salinity 
was $38.78 \pm 0.51$. Nitrite, nitrate and ammonium concentrations were measured weekly with aquarium Red Sea kits to ensure the proper functioning of the foam filters and associated circulation system.

\subsection{Experimental design}

On 12 March 2015 (day -5), incubations and biometry were carried out on three individuals per aquarium to ensure that the aquaria or pre-assigned batches $(\mathrm{C}, \mathrm{L} 1, \mathrm{~L} 2)$ had no effects on individual weight and metabolism of oysters before the viral inoculum injection (Table 1).

On 16 March, all the oysters in each aquarium were anesthetised in a solution containing magnesium chloride $\left(\mathrm{MgCl}_{2}: 50 \mathrm{~g}, 400 \mathrm{~mL}\right.$ seawater $+600 \mathrm{~mL}$ freshwater) (Suquet et al. 2009, Schikorski, Renault, et al. 2011). Control oysters (C) received a 'sham' injection of filtered seawater $(0.2 \mu \mathrm{m})$. Other oysters received a $50-\mu \mathrm{L}$ injection of one of the two viral inoculums, corresponding to two different viral loads (L1: $10^{8}$ or L2: $10^{9}$ OsHV-1 DNA copies per oyster) (Fig. 1). After injection, the oysters were transferred into their corresponding experimental aquaria, giving a total of nine aquaria ( 3 acclimation aquaria $\times 3$ treatments). During the experiment, the number of dead oysters was counted daily within a fixed batch of 20 oysters in each of the nine aquaria to determine mortality rates. The other 18 oysters were used in experimental incubations. Experiment duration was fixed to 14 days since mortality episode occurred within two weeks in the Thau lagoon (Pernet, Lagarde, Jeannée, et al. 2014). Nevertheless, 10 oysters par aquarium were keep in "acclimation" in each aquaria until the $21 \mathrm{~d}$ to confirm the end of the mortality episode. Before (d -5) and after injection, at days 1, 3, 7, 10 and 14, three oysters per aquarium were randomly sampled for incubation in individual chambers for the measurement of dissolved inorganic fluxes. These oysters were alive or dead, according to infection treatment and time. At the beginning of 
each incubation series, three chambers were filled with water (i.e. without oysters) to serve as a reference for fluxes (W). Thus, 36 incubations were performed per date $(3$ series $\times 4$ treatments $(\mathrm{W}, \mathrm{C}, \mathrm{L} 1$ and $\mathrm{L} 2) \times 3$ replicates: Fig. 1$)$.

\subsection{Metabolic chambers and incubation procedure}

Metabolic chambers, consisting of $125-\mathrm{mL}$ glass bottles $(\mathrm{H}: 102 \mathrm{~mm}, \varnothing 51 \mathrm{~mm})$ with rubber-sealed polypropylene caps (Fisher Brand 2911475), were equipped with a noninvasive optical oxygen sensor (PreSens) that adhered to the chamber wall. During the incubation procedure, 12 chambers $(\mathrm{W}, \mathrm{C}, \mathrm{L} 1, \mathrm{~L} 2 \times 3)$ plus three $125-\mathrm{mL}$ bottles $(\mathrm{W})$ were randomly deployed within an incubator, which was filled daily with filtered seawater $(<0.2$ $\mu \mathrm{m}$ ), maintained at $21^{\circ} \mathrm{C}$ and supersaturated with oxygen. Incubations were run for $2 \mathrm{~h} 30 \mathrm{~min}$ (i) in the dark in order to exclude photosynthesis and to ensure exclusive measurement of fluxes linked to respiration and mineralisation, (ii) in silence to avoid stressing the oysters and closing of the their valves. During the day, three series of incubations were performed using three incubators, located at three independent sites. Oysters were deprived of food $24 \mathrm{~h}$ prior to incubation.

At the beginning (T0) of each incubation procedure, three supplementary $125-\mathrm{mL}$ bottles deployed in each incubator were used to sample seawater to estimate the average nutrient concentrations at T0. Oxygen concentration was measured in each chamber using the noninvasive optical oxygen spot (SP-PSt3-NAU-D5-YOP) and an immovable optical fibre linked to a Fibox 3 optical oxygen meter (PreSens) at T0 and Tf (final time) using OxyView-PST3V6.02 software. Concentrations at Tf were estimated using the final sampling from each chamber. Water contained in the metabolic chambers was filtered using a syringe $(50 \mathrm{~mL})$ coupled with a fixed filter $(0.2 \mu \mathrm{m}$ cellulose acetate membrane). This water was next placed in two $60-\mathrm{mL}$ plastic bottles and stored at $-20^{\circ} \mathrm{C}$ for $\mathrm{NH}_{4}$ and $\mathrm{PO}_{4}$ analysis. At the end of the 
incubation, oysters were individually collected for biometry measurements. Oyster shells were removed and the flesh was snap frozen in liquid nitrogen and stored at $-80^{\circ} \mathrm{C}$ for dry weight and qPCR analyses.

\subsection{Mortality kinetic, oyster biometry and dissolved inorganic flux analysis}

The cumulative mortality rates were calculated each day in each of the nine aquaria from the sums of dead oyster numbers observed from day 1 compared to the initial oyster number $(\mathrm{n}=20)$. The lengths were determined with a calliper and total, flesh and shell weights were determined with a precision balance to $10^{-3} \mathrm{~g}$. The AFNOR condition index (flesh weight/total weight) was calculated for each sampled oyster. The $\mathrm{PO}_{4}$ and $\mathrm{NH}_{4}$ concentrations were measured using Seal AA3 analytical autoanalysers following previously described methods (Aminot and Kérouel 2007) with colorimetric (from SEAL Analytical, Germany) and fluorometric (from JASCO, FP-2020plus, France) detection, respectively. The Ifremer laboratory in Sète is accredited for these analyses in accordance with the recognised international standard ISO/IEC 17025, by the French Committee for Accreditation (COFRAC, Certificate $\left.\mathrm{n}^{\circ} 1-1655\right)$. The $\mathrm{O}_{2}$ and nutrient fluxes were determined from changes in concentrations between $\mathrm{Tf}$ and $\mathrm{T} 0$, reported for incubation duration and multiplied by chamber volume. These data are expressed as $\mu \mathrm{mol} \cdot \mathrm{h}^{-1}$.chamber ${ }^{-1}$.

\subsection{Nucleic acid extraction and PCR detection of $O s H V-1$}

OsHV-1 DNA was detected and quantified. Genomic DNA was purified from oyster tissues using the Wizard® SV Genomic DNA Purification System (Promega). Whole animal samples previously stored at $-80^{\circ} \mathrm{C}$ were homogenised on ice in a $1.5-\mathrm{mL}$ microtube using a pellet mixer in the digestion solution and incubated for 2 hours at $55^{\circ} \mathrm{C}$. The remaining oyster tissues were pelleted (centrifugation at $2000 \mathrm{~g}$ for $2 \mathrm{~min}$ ) and DNA was extracted from the supernatant according to the manufacturer's instructions. Samples were resuspended to a final 
concentration of $20 \mathrm{ng} \cdot \mu \mathrm{L}^{-1}$. OsHV-1 genomic DNA was detected and quantified using quantitative PCR (qPCR) (Pepin et al. 2008). All amplification reactions were performed in duplicate using a Roche LightCycler 480 Real-Time thermocycler (qPHD-Montpellier GenomiX platform, Montpellier University). The PCR reaction volumes were $6 \mu \mathrm{L}$ and contained LightCycler 480 SYBR Green I Master mix (Roche), $100 \mathrm{nM}$ of pathogen-specific primers and 20 ng of DNA. Pathogen-specific primer pairs C9/C10 were obtained from the literature (Barbosa-Solomieu et al. 2004, Schikorski, Faury, et al. 2011) and their resulting amplification products were cloned into the pCR4-Topo vector and replicated in Escherichia coli DH5a (Invitrogen). Plasmids were extracted using the Wizard Plus SV miniprep DNA purification system (Promega) and standard curves of known concentration of plasmid were generated according to the Applied Biosystems manual of absolute real-time RT-PCR quantification. Absolute quantification of OsHV-1 genome copies in oyster samples was estimated by comparing the observed $\mathrm{Cp}$ values to known plasmid standards.

\subsection{Statistical analysis}

PERMANOVAs were used to test the effects of i) infection treatment, date and their interaction on mortality, biometry and flux results; and ii) oyster status (dead, infected and control oysters) on fluxes and nutrient ratios. First series of PERMANOVAs was done to test the influence of mortality episode on dissolved fluxes, considering alive and dead organisms, to describe mean changes at individual scale from a small number of organisms $(n=9)$. The idea was to extrapolate data from individual to lantern scale in order to simulate changes observed in the field before within and after a mortality episode. The second PERMANOVAs series was done to dissociate processes highlighting (i) the influence of infection on metabolism (respiration and excretion) of oyster, and (i) the effect of flesh decomposition on oxygen demand and ammonium and phosphate fluxes, in considering separately fluxes measured at the interface of infected (L) and dead oysters (D). A posteriori tests were then 
done to compare individual means with each other where there was significant variation. Analyses were done with JMP, PRIMER software and the PERMANOVA package (Plymouth Routines in Multivariate Ecological Research; Clarke and Warwick 2001).

\section{Results}

\subsection{Cumulative mortality rates}

Cumulative mortality rates varied significantly with the interaction of date and treatment $(\mathrm{N}=126$, $\mathrm{p}$-value $<0.0001)$. No mortality was observed during the first two days after viral injection within each infection treatment, but the first dead oysters were observed at day 3 in treatments L1 and L2. From day 4 until day 14, cumulative mortality rates were significantly higher in infected (L1, L2) than in control (C) treatments, with no significant differences between L1 and L2 (Fig. 2). At day 14, the cumulative mortality rates ( \pm SE) were 0, $34.5 \pm$ 2.7 and $41.6 \pm 5.8$ for C, L1 and L2 treatments, respectively. For information, no dead oyster was observed at day 21 whatever treatments.

\subsection{Biometry}

At d-5, the mean length and total weight $( \pm \mathrm{SE})$ of the oyster juvenile were $17.7 \pm 0.4 \mathrm{~mm}$ and $1.06 \pm 0.01 \mathrm{~g}$, respectively. From day 1 to day 14 , the total weight of live oysters varied significantly with infection treatment $(\mathrm{p}=0.004)$ and date $(\mathrm{p}=0.002)(\mathrm{N}=135)$. The total weight was higher in the control than in the infected oysters, with no difference between viral loads (C: $1.16 \pm 0.01$ vs. L1 and L2: $1.12 \pm 0.005)$. A slight increase was observed in the total weight and shell weight from d1 to d7, specifically for the C oysters. By contrast, neither flesh weight nor AFNOR condition index varied significantly among treatments during the 
experiment (d1 to $\mathrm{d} 14)$. The means $( \pm \mathrm{SE})$ were $0.158 \pm 0.003 \mathrm{WWg}$ and $14.04 \pm 0.22$, respectively, when the data were pooled within date $(\mathrm{d} 1, \mathrm{~d} 3, \mathrm{~d} 7, \mathrm{~d} 10$ and $\mathrm{d} 14)$ and infection treatment $(\mathrm{C}, \mathrm{L} 1$ and $\mathrm{L} 2)$.

\subsection{Viral DNA}

The number of viral DNA copies per ng total gDNA (NVDC), quantified for the flesh of live oysters varied significantly according to the interaction between date and treatment $(\mathrm{p}=$ 0.015) $(\mathrm{N}=45)$. No significant variation was observed between $\mathrm{C}, \mathrm{L} 1$ and $\mathrm{L} 2$ at $\mathrm{d} 1$ or $\mathrm{d} 14$, but higher NVDC values were observed in infected than in control treatments at $d 3, d 7$ and d10 (Fig. 3A). Intra-treatment variability was significantly higher in the L treatments, specifically for L2 at $\mathrm{d} 3$ and $\mathrm{d} 7$ (Fig. 3). The a posteriori tests showed that the NVDC observed for L1 increased at $\mathrm{d} 3$, followed by a decrease at $\mathrm{d} 7$ and a minimal value at $\mathrm{d} 14$. By contrast, the NVDC observed for L2 significantly increased from d3 until d10 and finally decreased at d14 (Fig. 3). The status of the oysters (C: control, L: infected, D: dead) was a significant source of variation for the NVDC $(p=0.0001)$, with the highest mean observed for dead organisms and the lowest for the control oysters $(\mathrm{C}: 1.81 \mathrm{E}+01<\mathrm{L}: 1.13 \mathrm{E}+04<\mathrm{D}$ : 1.54+05 C9C10 copies.ng of total gDNA: Fig. 3B).

\subsection{Dissolved fluxes}

During the experiment, live and dead oysters were randomly incubated within individual chambers, with increase of numbers of incubated dead organisms from $\mathrm{d} 3$ to $\mathrm{d} 14$, in the infected treatments (Fig. 4). The $\mathrm{O}_{2}, \mathrm{NH}_{4}$ and $\mathrm{PO}_{4}$ fluxes varied significantly according to treatment (W, C, L1 and L2) and date, based on the fluxes at the interface of live and dead oysters (Table 2). More specifically, the presence of oysters was a significant source of 
variation for dissolved fluxes, with higher consumption of $\mathrm{O}_{2}$ and higher releases of $\mathrm{NH}_{4}$ and $\mathrm{PO}_{4}$ in the presence $(\mathrm{C}, \mathrm{L} 1$ and L2) than in the absence of oysters (W) (cf. a posteriori tests in Table 2 and * Figure 5). Consideration of the biogeochemical fluxes associated with live and dead oysters in the dataset (Table 2, Fig. 5) resulted in: i) a significant effect of infection treatments (L1, L2 vs. C) for $\mathrm{O}_{2}$ fluxes, with lower consumption observed for infected than for control oysters (Fig. 5A), ii) high $\mathrm{NH}_{4}$ and $\mathrm{PO}_{4}$ releases for $\mathrm{L}$ treatments at d7, d10 and d14 (Fig. 5B, C). The PERMANOVAs showed that the status of the oysters (dead, infected or control) had a significant effect on the fluxes of $\mathrm{O}_{2}, \mathrm{NH}_{4}$ and $\mathrm{PO}_{4}$, (i) with lower $\mathrm{O}_{2}$ consumption and $\mathrm{NH}_{4}$ release for the infected oysters than the controls (Fig. 6A, B, Table 3), (ii) with lower $\mathrm{O}_{2}$ consumption and higher $\mathrm{NH}_{4}$ and $\mathrm{PO}_{4}$ release at the interface of dead than of live oysters (i.e. C or L: Table 3, Fig. 6A, B, C). The oxygen demand observed at the interface of the dead organisms corresponded to $2 / 3$ of the oxygen consumption of the control oysters. Dead oysters lead to very high ammonium and phosphate releases, especially at d7 when the mean release at the interface of dead organisms $\left(0.58 \mu \mathrm{molNH}_{4} \cdot \mathrm{h}^{-1} \cdot\right.$. $^{-1} \mathrm{~d}^{-1} 0.044$ $\mu \mathrm{molPO}_{4} \cdot \mathrm{h}^{-1}$.ind ${ }^{-1}$ ) was 14 to 63 fold higher than that observed at the interface of live oysters $\left(0.04 \mu \mathrm{mol} \mathrm{NH} 4 \cdot \mathrm{h}^{-1}\right.$.ind ${ }^{-1} ; 0.0007 \mu \mathrm{molPO}_{4} \cdot \mathrm{h}^{-1}$. nd $\left.^{-1}\right)$, respectively. $\mathrm{NH}_{4}$ and $\mathrm{PO}_{4}$ releases at the dead oyster interface were on average 6 to 41 fold higher than ones observed at the interface of control oysters (Fig. 6B, C). Releases of $\mathrm{NH}_{4}$ and $\mathrm{PO}_{4}$ did not show the same proportions at the interface of control, infected or dead organisms. Thus, $\mathrm{NH}_{4} / \mathrm{PO}_{4}$ concentration ratios observed at final time of incubation (Tf) varied significantly according to oyster status (Table 3), with lower mean ratios for dead, followed by infected and control oysters $\left(\mathrm{NH}_{4} / \mathrm{PO}_{4}\right.$ : D: $11.3<\mathrm{L}: 22.4<\mathrm{C}: 35.4$, Fig. 7C).

\section{Discussion}


In our study, we reproduced OsHV-1 infection by injection, as previously done by Schikorski et al. (2011b), maintaining oysters in standard conditions used in ecophysiology, with the objective to test the influence of oyster mortality episode on dissolved inorganic fluxes at the water-shell oyster interface, dissociating (i) the effect of a viral infection on metabolism (i.e. respiration and excretion rates) of oyster juveniles and (ii) the effect of flesh decomposition on oxygen consumption and nutrient release at the water-oyster interface at the individual scale.

\subsection{Incidence of viral injection in juvenile oysters and kinetics of mortality}

As expected, and as previously described by Schikorski et al. (2011b), intramuscular injection of OsHV-1 viral inoculum caused mortality in Crassostrea gigas, with the first dead oysters appearing three days after infection. The kinetics of mortality were slower in our study than typically observed in experimental pathology studies (Schikorski, Faury, et al. 2011, Schikorski, Renault, et al. 2011, Segarra et al. 2016) (Fig. 7), with cumulative mortality rates of $2.5,15$, and $40 \%$ at $\mathrm{d} 3, \mathrm{~d} 7$ and $\mathrm{d} 14$, respectively, vs. $40-70$ and $60-90 \%$ at $\mathrm{d} 3$ and $\mathrm{d} 7$, respectively (Schikorski, Faury, et al. 2011, Schikorski, Renault, et al. 2011). The variability in the mortality kinetics and magnitude could have been linked to differences in the injected viral loads, but it was not the case. We used higher loads than in other studies $\left(10^{8}\right.$ and $10^{9}$ vs. $2 \times 10^{4}$ to $1.5 \times 10^{7}$ viral DNA copies per oyster : Schikorski et al., 2011a, 2011b). We chose these doses after preliminary tests indicated that $10^{8}$ viral DNA copies per oyster of our inoculum induced mortality. Our inoculum could possibly be less virulent than others, or else the quantification of DNA copies may not be a good indicator of virulence since real time quantitative PCR does not allow the quantification of infective virus particles, which are necessary to initiate the virus infection in host cells (Lyman \& Enquist 2009). PCR 
quantification does not give information about the status of viral capsids and membranes, which may be damaged, but we are unable to test this hypothesis. Variability of resistance traits between oyster juveniles used in this study with the other ones (Schikorski, Faury, et al. 2011, Schikorski, Renault, et al. 2011) could also explain this result. Nevertheless, the used oyster ("Naissain Standard Ifremer") were produced from large pool of broodstock sampled in the field (Petton, Boudry, et al. 2015) and they supposed to be free of pathogens and not resistant to OsHV-1. However, the oyster stocking methods used in our study were not the same as those used in experimental pathology studies. We maintained oysters in standard conditions used in ecophysiology. In contrast to other studies, oysters were at low density (our study: 38 ind. 1 g / 60 L: 0.6 g.L - $^{-1}$ vs. Schikorski et al. 2011 a: 140 ind. 5 g / 25 L: 28 g.L , $^{-1}$ Schikorski et al., 2011b: 10 ind.5 g / 5 L: 10 g.L $\mathrm{L}^{-1}$ ). Oysters were fed daily with Skeletonema sp. and seawater was continuously filtered through a foam filter and aerated with an airlift. The differences in stocking methods between our study and previous ones could also explain differences in mortality kinetics and magnitude. These conditions were chosen to avoid potential stress linked to starvation, hypoxia and excess ammonium and nitrite that could favour infection, mortality and metabolic changes. Finally, the low oyster density and filtration of seawater used in our study might have limited horizontal transmission processes induced by oyster cohabitation, as previously described in (Schikorski, Faury, et al. 2011, Petton, Boudry, et al. 2015), and caused by releases of viral particles in seawater on the first day after infection (Schikorski, Faury, et al. 2011, Paul-Pont et al. 2015). These slow kinetics of mortality and intermediate cumulative mortality were also observed with diluted viral inoculum (Paul-Pont et al. 2015), which is adequate for conducting research on changes in metabolism in response to infection. Finally, our observations were comparable to those reported in natural environments, notably in the Thau lagoon (France), where cumulative 
mortality rates were $2.5-5 \%$ at the beginning of a mortality episode and reached $12-30 \%$ and $40-47 \%$ at 7 and 14 days after the first observations of moribund and dead organisms (Fig. 7).

The mortality of oysters in our study was due to OsHV-1 infection, as no mortality was observed in control oysters injected with filtered seawater. Higher numbers of OsHV-1 DNA copies were observed in the flesh of live infected oysters from $\mathrm{d} 1$ to $\mathrm{d} 3$ suggesting that OsHV-1 is the causative agent of the mortalities. However, as mentioned by previous studies (Petton, Bruto, et al. 2015), we cannot exclude the role of pathogenic bacteria, especially vibrios, in the pathogenesis as co-factors of mortality. As suggested by Sauvage et al. (2009), the $\mathrm{d} 1-\mathrm{d} 3$ period may correspond to a replication phase that leads to irreversible cell damage before resulting in the first instances of mortality. The highest copy number for OsHV-1 DNA was observed between $\mathrm{d} 3$ and d10, with high individual variability. This result suggested that active virus replication occurred during this period in the injected oysters, as described by Schikorski et al. (2011b). The highest amounts of viral DNA were observed in dead oysters, followed by infected and control oysters (D: $1.54 \times 10^{5}>\mathrm{L}: 1.13 \times 10^{4}>\mathrm{C}: 1.81 \times 10^{1} \mathrm{DNA}$ copies $\mathrm{ng}^{-1}$ of total DNA extracted from tissues). The same range of viral DNA amounts was observed previously in dead and dying oyster juveniles (Schikorski et al., 2011a, 2011b; Segarra et al., 2016).

The quantity of viral particles reaches a threshold in oyster tissues before death (Paul-Pont et al. 2015). Thus, infected oysters, dissected alive, showed significantly lower viral concentrations in their tissues than dead oysters (Paul-Pont et al. 2015). At the end of our experiment, from 1 to 2 viral DNA copies $\mathrm{ng}^{-1}$ of total DNA were recorded in the flesh of live oysters, regardless of their infection treatment. Surviving oysters at d14 were probably genetically more resistant to the disease than others, as previously observed (Segarra et al. 2014) in a family selected for low susceptibility. 
After 21 days, no further mortality was observed in the infected oysters. This result indicated the end of active infection and effective control of viral replication in the surviving oysters, as shown previously for juvenile oysters (He et al. 2015). Arzul et al. (2002) reported the detection of low virus DNA amounts in healthy oysters and suggested that these organisms corresponded to healthy carriers. Finally, no significant difference was observed in terms of mortality magnitude and kinetics between the two viral doses used in this study. A dose-response relationship between the load of OsHV-1 viral inoculum and mortality rate was reported in C. gigas by Paul-Pont et al. (2015). A sufficient initial dose of viral particles is needed to trigger mortality. It is likely that this threshold was exceeded in our study.

\subsection{Impact of viral infection on juvenile metabolism}

Our study showed, under laboratory conditions, that oysters (i) consume oxygen via respiration processes and (ii) release ammonium and phosphate via excretion processes. The mean observed respiration rate $\left(21.94 \mu \mathrm{molO}_{2} . \mathrm{gDW} . \mathrm{h}^{-1}\right)$ was of the same order of magnitude than data reported in the literature (Table 4), that ranged from 23.6 to $33.6 \mu \mathrm{molO}_{2} \cdot \mathrm{DWg}^{-1} \cdot \mathrm{h}^{-1}$ for $C$. gigas at $20^{\circ} \mathrm{C}$ with lower rates observed for juveniles. Respiration rates vary according to temperature, size, food availability, salinity and stressors (Gosling 2015a).

Ammonia is the main product excreted by marine bivalves (Gosling 2015a). The $\mathrm{NH}_{4}$ excretion rates observed in our study were consistent with those obtained previously by Buzin et al. (2015), varying from 0.2 to $0.8 \mu \mathrm{molNH}_{4} \cdot \mathrm{DWg}^{-1} \cdot \mathrm{h}^{-1}$ according to temperature (Table 4). To our knowledge, no study has yet quantified phosphate excretion of marine bivalves at the individual scale. More often, phosphate release was documented at the community scale, i.e. at the interface of bivalve beds (Dame et al. 1989, Dame and Libes 1993, Asmus et al. 1995, Bartoli et al. 2001), rearing structures (Richard et al. 2007, Jansen et al. 2011, Lacoste and Gaertner-Mazouni 2016) or pools (Richard et al. 2006). These releases were attributed to 
mineralisation processes and excretion of benthic organisms, mainly represented by engineering species (i.e. oysters or mussels) in terms of biomass. In our study, the mean ratio between ammonium and phosphate excretion rates was 46 for the control oyster juvenile. A ratio of 35 was obtained between $\mathrm{NH}_{4}$ and $\mathrm{PO}_{4}$ concentrations at the end of the incubation, which was higher than that reported previously for phytoplankton $(\mathrm{N}: \mathrm{P}=16: 1$; Redfield et al., 1963). This observation illustrates that oysters act as an important sink for phosphorus, as highlighted by Dame et al. (1989) for oyster reefs, which released only $8 \%$ of TP uptake as $\mathrm{PO}_{4}$

Several authors have highlighted, in an infection context, that bivalve diseases induce changes in filtration activities (Table 5); however, few have highlighted the variations in respiration and excretion activities of these infected organisms. Most of the cited papers listed in Table 5 focus on parasites (i.e. Martelia, Perkinsus marinus, Haplosporidium nelsoni, etc.), whereas few focused on bacteria and none investigated viral infection. To our knowledge, our study highlights for the first time that OsHV-1 infection induces a decrease in oxygen consumption and ammonium excretion by oyster juvenile. These results could be linked to the alteration of gill and heart cells, which have been characterised as targets for OsHV-1 replication (Arzul et al. 2002, Pépin et al. 2008, Sauvage et al. 2009, Schikorski, Faury, et al. 2011, Segarra et al. 2016) and are actively involved in respiration and excretion processes (Gosling 2015a, b).

Soletchnik et al. (1998) showed a negative correlation between respiration and gill abnormalities induced by Chlamia in C. gigas and related it to gill malfunction. Ruditapes philippinarum showed a parallel decrease in respiration and clearance rate in cases of infection by Vibrio tapetis (Flye-Sainte-Marie et al. 2007). These authors interpreted this respiration decrease as a compensatory reduction in the metabolic rate depending on feeding activity. No measurements of clearance rates were made in the present study; nevertheless, we 
assume that the filtration activity of oyster juvenile may be reduced in cases of OsHV-1 infection. We also assume that mucus secretion, observed at the extremity of valves of some infected oysters, would inhibit gill ciliary activities and in turn perturb filtration activities, as suggested by Flye-Sainte-Marie et al. (2007) for R. philippinarum infected with V. tapetis.

The valve-activity behaviour of infected oysters was modified during infection prior to death. When they were still alive, the infected oysters seemed to show longer and wider valve opening, so that the oyster juvenile seemed to be less reactive to external stress. The same phenomenon was observed with oysters infected with Perkinsus marinus (Mackin 1962) which could not maintain valve as long as uninfected oysters. In the present study, this behaviour did not appear to show a correlation with respiration or excretion rates. The adductor muscles are also targets for OsHV-1 replication (Schikorski, Faury, et al. 2011), so infection could also induce dysfunction in their valve-closing function. Future experiments should attempt to confirm this observation with a valvometer as done by (Tran et al. 2010, Comeau et al. 2017). Changes in valve-opening behaviour could be a good indicator for predicting OsHV-1 mortality in the field.

\subsection{Impact of flesh decomposition on dissolved fluxes}

Our study showed for the first time that oyster mortality induced large releases of $\mathrm{NH}_{4}(\times$ 6) and $\mathrm{PO}_{4}(\times 41)$ via decomposition of flesh. Similar results were shown with decomposed mussels (Lomstein et al. 2006) and jellyfish (West et al. 2009, Chelsky et al. 2016). Nitrogen and phosphorus releases may result from leaching, followed by microbial mineralisation of dead tissue (West et al. 2009). A succession of bacteria are involved in oyster spoilage, including mainly proteobacteria such as Vibrio sp. (Madigan et al. 2014). 
Bacteria are bio-accumulated mainly in the gills and digestive glands (Dapeng et al. 2014). In the present study, decomposition of oyster tissues was first observed in the mantle and gills and finally the digestive gland. Kasper et al. (2012) made a detailed description of the decomposition and mineralisation of decaying cadavers. The decay of a dead body typically starts under the influence of aerobic bacteria that deplete the body of oxygen. Oxygen consumption observed at the dead oyster interface could therefore be related to the biological oxygen demand exerted by these kinds of aerobic bacteria. Subsequently, decomposition continues with putrefaction by anaerobic bacteria. Putrefaction occurs predominantly by reductive processes and is accompanied by the production of putrefaction compounds, such as ammonia and hydrogen sulfide (Kasper et al. 2012).

Oxidation of these reduced compounds could also explain the increased oxygen demand observed at the dead oyster interface. Biological and chemical oxygen demands corresponded to half the oxygen consumption of uninfected oysters. Kasper et al. (2012) also noted that high molecular nutrients break down to their constituents. Thus, proteins degrade via peptides and amino acids to smaller sulfur-, nitrogen- and phosphorus-containing compounds. Triacylglycerides are saponified into glycerine and free fatty acids. Polysaccharides are hydrolysed into glucose and monosaccharides, which are typically decomposed to organic acids and other oxygenated compounds. Microbial activity on these low-molecular precursor substances leads to volatile organic compounds, responsible for the intense smell of decaying organisms. The efflux of fatty acids and dissolved organic nitrogen and phosphorus (DON and DOP, respectively) were also observed during decomposition of mussels and jellyfish (Lomstein et al. 2006, West et al. 2009). The volume of our metabolic chambers was too small to carry out both inorganic and organic $\mathrm{N}$ and $\mathrm{P}$ analyses. Nevertheless, we supposed that the increased decomposition of oysters also increased DON and DOP fluxes. 
Releases from decaying organisms are called necronomes (Stroud et al. 2013). These necronomes can act as semiochemical signals, which are involved in animal communication. Certain semiochemicals, such as certain unsaturated fatty acids (oleic and linoleic acid), trigger strong necrophoric behaviour in isopod crustaceans (Yao et al. 2009 in Stroud et al. 2013). These kinds of organisms were observed in oyster lantern nets in the Thau lagoon during oyster mortality events. In our study under laboratory conditions, we did not take into consideration the role of scavengers in oyster degradation. Without predation, high ammonium releases at the interface of dead oysters may reduce the probability or amplitude of $\mathrm{N}$ deficiency in adjacent water, as found for healthy oysters in the adult stage (Souchu et al. 2011) or with mussels (Richard et al. 2006). Ammonia release at the interface of dead organisms may stimulate primary production and specifically favour blooms of small-sized phytoplankton, i.e. picophytoplankton, as observed for oysters at the adult stage (Chapelle et al. 2000, Souchu et al. 2001).

High inputs of $\mathrm{PO}_{4}$ related to oyster decomposition may increase the abundance of prokaryotes, pico-eukaryotes and cyanobacteria, as observed during a $\mathrm{P}$ enrichment experiment in mesocosms (Tsiola et al. 2015). Disequilibria in ammonia and phosphorus release kinetics were observed depending on oyster status, with lower N/P ratios observed at the dead oyster interface $\left(\mathrm{NH}_{4} / \mathrm{PO}_{4}\right.$ at final time (Tf): D: 11.3 , L: 22.4, C: 35.4). Justic et al. (1995) and Peñuelas et al. (2013) also reported that changes in the original nutrient ratios may induce changes in the specific composition of plankton communities. Considering that (i) growth of heterotrophic prokaryotic tend to be limited by P (Tsiola et al. 2016), and (ii) the reported molar C:N:P ratios of bacteria were near 45:9:1 (Goldman et al. 1987) and 50:10:1 (Fagerbakke et al. 1996), the disequilibria in ammonia and phosphorus releases observed during flesh decomposition may favour bacterial proliferation. Thus, decomposition and 
mineralisation of oyster flesh may modify the structure of the planktonic community during mortality episodes.

\section{Conclusions and Perspectives}

Our study highlighted for the first time, under laboratory conditions, that dissolved inorganic fluxes varied during a mortality episode since (i) OsHV-1 infection modifies oyster juvenile metabolism, with significant decreases in oxygen consumption and ammonium excretion; (ii) mortality of oysters leads to a profound increase in ammonium $(\times 6)$ and phosphate $(\times 41)$ releases and disequilibria in nutrient release kinetics at the water-dead oyster interface, due to mineralisation of flesh. Based on individual rates, fluxes were extrapolated to a lantern net scale (Table 6). Calculations showed that (i) a slight decrease (30-40\%) in oxygen consumption, (ii) a large increase in ammonia $(\times 2-5)$ and phosphate $(\times 8-19)$ releases and (iii) a decrease in the N/P ratio would be observed at the lantern net interface during mortality episodes, depending on the magnitude of these events (30-100\% mortality). These estimated values will be compared with ones measured using pelagic chambers in the Thau lagoon as part of the second study of the Mortaflux program. This in situ experiments will help us to (i) confirm this abnormal nutrient loading during mortality episode, and (ii) demonstrate their influence in planktonic components (bacterio-, phyto and proto-plankton). Finally, this study will help us to elucidate pathogen transfers occurring during mortality episodes. This series of study is pioneer in its kind as it highlighted for the first time the consequences of the phenomena of oyster mortality on the cycle of matter.

\section{Acknowledgements}


This work is a contribution to the MORTAFLUX program, funded by the Scientific Direction of Ifremer and by the EC2CO BIOHEFECT. The Master II fellowship of J. Bourreau was financed by the Marbec Unit. The authors thank Emmanuel Rezzouk, François Ruelle et al. for allowing us to use the experimental platform of the Ifremer Palavas Station to carry out this first series of experiments. Many thanks to B. Petton and M. Nourry to give us NSI juvenile (Naissain Standard Ifremer) and to M. Alunno-Bruscia for her help on anesthesia protocol. Authors thank the MORTAFLUX collaborators for discussions about experimental design and stocking methods of this first step: B. Mostajir, JL. Rolland, B. Bec, F. Lagarde, S. Mortreux, S. Mas, D. Parin. We thank the "Bureau de Traduction de l'Université de Brest Occidentale" for their correction of the English.

\section{References}

Aminot A, Kérouel R (2007)Dosage automatique des nutriments dans les eaux marines, Ifremer. Brest

Anestis A, Pörtner HO, Karagiannis D, Angelidis P, Staikou A, Michaelidis B (2010) Response of Mytilus galloprovincialis (L.) to increasing seawater temperature and to marteliosis: metabolic and physiological parameters. Comp Biochem Physiol A Mol Integr Physiol 156:57-66

Arzul I, Renault T, The A (2002) Detection of oyster herpesvirus DNA and proteins in asymptomatic Crassostrea gigas adults. 84:151-160

Asmus H, Asmus RM, Zubillaga GF (1995) Do mussel beds intensify the phosphorus exchange between sediment and tidal waters? Ophelia 41:37-55

Barbosa Solomieu V, Renault T, Travers M-A (2015) Mass mortality in bivalves and the intricate case of the Pacific oyster, Crassostrea gigas. J Invertebr Pathol 131:2-10

Barbosa-Solomieu V, Miossec L, Vázquez-Juárez R, Ascencio-Valle F, Renault T (2004) Diagnosis of Ostreid herpesvirus 1 in fixed paraffin-embedded archival samples using PCR and in situ hybridisation. J Virol Methods 119:65-72

Bartoli M, Nizzoli D, Viaroli P, Turolla E, Castaldelli G, Fano EA, Rossi R (2001) Impact of Tapes philippinarum farming on nutrient dynamics and benthic respiration in the Sacca di Goro. Hydrobiologia 455:203-212 
Bernard F, Noakes D (1990) Pumping rates, water pressures, and oxygen use in Eight species of marine bivalve molluscs from British Columbia. Can J Fish Aquat Sci 47:1302-1306

Bougrier S, Geairon P, Deslous-Paoli J-M, Bacher C, Joncquières G (1995) Allometric relationships and effects of temperature on clearance and oxygen consumption rates of Crassostrea gigas ( Thunberg ). Aquaculture 134:143-154

Broekhoven W van, Troost K, Jansen H, Smaal A (2014) Nutrient regeneration by mussel Mytilus edulis spat assemblages in a macrotidal system. J Sea Res 88:36-46

Buestel AD, Ropert M, Prou J, Goulletquer P (2009) History, Status , and Future of Oyster Culture in France. J Shellfish Res 28:813-820

Buzin F, Dupuy B, Lefebvre S, Barillé L, Haure J (2015) Aquacultural Engineering Storage of Pacific oysters Crassostrea gigas in recirculating tank : Ammonia excretion and potential nitrification rates. Aquac Eng 64:8-14

Callier MD, Richard M, McKindsey CW, Archambault P, Desrosiers G (2009) Responses of benthic macrofauna and biogeochemical fluxes to various levels of mussel biodeposition: An in situ "benthocosm" experiment. Mar Pollut Bull 58:1544-1553

Callier MD, Weise AM, McKindsey CW, Desrosiers G (2006) Sedimentation rates in a suspended mussel farm (Great-Entry lagoon, Canada): biodeposit production and dispersion. Mar Ecol Prog Ser:129-141

Chapelle A, Ménesguen A, Deslous-Paoli J-M, Souchu P, Mazouni N, Vaquer A, Millet B (2000) Modelling nitrogen, primary production and oxygen in a Mediterranean lagoon. Impact of oysters farming and inputs from the watershed. Ecol Modell 127:161-181

Chelsky A, Pitt K a, Ferguson AJP, Bennett WW, Teasdale PR, Welsh DT (2016) Decomposition of jellyfish carrion in situ: Short-term impacts on infauna, benthic nutrient fluxes and sediment redox conditions. Sci Total Environ 566-567:929-937

Clarke KR, Warwick RM (2001) Changes in Marine Communities: An Approach to Statistical Analysis and Interpretation, 2nd Edition. PRIMER-E, Plymouth Marine Laboratory, UK

Comeau L a., Mallet A, Carver C, Nadalini J-B, Tremblay R (2017) Behavioural and lethal effects of sediment burial on quiescent Eastern oysters Crassostrea virginica. Aquaculture 469:9-15

Corporeau C, Tamayo D, Pernet F, Quéré C, Madec S (2014) Proteomic signatures of the oyster metabolic response to herpesvirus OsHV-1 $\mu$ Var infection. J Proteomics:1-12

Cranford P, Dowd J, Grant J, Hargrave B, McGladerry S (2003) Ecosystem level effects of marine bivalve aquaculture. In A scientific review of the potential environmental effects of aquaculture in aquatic ecosystems. Can Tech Rep Fish Aquat Sci 1:51-93 
Dame RF (1972) The Ecological Energies of Growth, Respiration and Assimilation in the Intertidal American Oyster Crassostrea virginica *. Mar Biol:243-250

Dame R, Libes S (1993) Oyster reefs and nutrient retention in tidal creeks. J Exp Mar Bio Ecol 171:251-258

Dame RF, Spurrier JD, Wolaver TG (1989) Carbon, nitrogen and phosphorus processing by an oyster reef. Mar Ecol Prog Ser 54:249-256

Dapeng W, Qian Z, Yan C, Xianming S (2014) Seasonal dynamics and diversity of bacteria in retail oyster tissues. Int J Food Microbiol 173:14-20

Davison AJ, Trus BL, Cheng N, Steven AC, Watson MS, Cunningham C, Deuff R-M Le, Renault T (2005) A novel class of herpesvirus with bivalve hosts. J Gen Virol 86:41-53

Dégremont L (2013) Size and genotype affect resistance to mortality caused by OsHV-1 in Crassostrea gigas. Aquaculture 416-417:129-134

Deuff R-M Le, Renault T (1999) Purification and partial genome characterization of a herpeslike virus infecting the Japanese oyster , Crassostrea gigas. J Gen Virol 80:1317-1322

Dupuy C, Vaquer A, Lam-Thoï T, Rougier C, Mazouni N, Lautier J, Collos Y, Gall S Le (2000) Feeding rate of the oyster Crassostrea gigas in a natural planktonnic community of the Mediterranean Thau lagoon. Mar Ecolgy Prog Ser 205:171-184

Fagerbakke KM, Heldal M, Norland S (1996) Content of carbon, nitrogen, oxygen, sulfur and phosphorus in native aquatic and cultured bacteria. Aquat Microb Ecol 10:15-27

Filgueira R, Comeau L, Guyondet T, McKindsey CW, Byron C (2015) Modeling Carrying capacity of bivalve Aquaculture: A review of Definitions and Methods. In: Meyers RA (ed) Encyclopedia of Sustainability Science and Technology. Springer New York, New York, NY, p 1-33

Filgueira R, Guyondet T, Comeau L a., Grant J (2014a) Physiological indices as indicators of ecosystem status in shellfish aquaculture sites. Ecol Indic 39:134-143

Filgueira R, Guyondet T, Comeau L a., Grant J (2014b) A fully-spatial ecosystem-DEB model of oyster (Crassostrea virginica) carrying capacity in the Richibucto Estuary, Eastern Canada. J Mar Syst 136:42-54

Flye-Sainte-Marie J, Pouvreau S, Paillard C, Jean F (2007) Impatc of Brown Ring Disease on the energy budget of the Manila clam Ruditapes philippinarum. J Exp Mar Bio Ecol 349:378-389

Forrest BM, Keeley NB, Hopkins GA, Webb SC, Clement DM (2009) Bivalve aquaculture in estuaries: Review and synthesis of oyster cultivation effects. Aquaculture 298:1-15 
Froján M, Arbones B, Zúñiga D, Castro C, Figueiras F (2014) Microbial plankton community in the Ría de Vigo (NW Iberian upwelling system): impact of the culture of Mytilus galloprovincialis. Mar Ecol Prog Ser 498:43-54

Gale LD, Manzi JJ, Crosby MP (1991) Energetic costs to the Eastern oyster Crassostrea virginica due to recent parasitism by the ectoparasitic gastropod Boonea impressa *. Mar Ecol Prog Ser 79:89-98

Garcia C, Thébault A, Dégremont L, Arzul I, Miossec L, Robert M, Chollet B, François C, Joly J, Ferrand S, Kerdudou N, Renault T (2011) Ostreid herpesvirus 1 detection and relationship with Crassostrea gigas spat mortality in France between 1998 and 2006. Vet Res 42:1-11

Girard S, Pérez Agúndez J a. (2014) The effects of the oyster mortality crisis on the economics of the shellfish farming sector: Preliminary review and prospects from a case study in Marennes-Oleron Bay (France). Mar Policy 48:142-151

Goldman JC, Caron DA, Dennett MR (1987) Regulation of gross growth efficiency and ammonium regeneration in bacteria by substrate $C:$ N ratio. Limnol Oceanogr 32:12391252

Gosling E (2015a) Circulation, respiration, excretion and osmoregulation. In: Wiley JS (ed) Marine Bivalve Molluscs2. Wiley, John; Sons, p 243-264

Gosling E (2015b) How bivalves feed? In: Wiley J, Sons (eds) Marine Bivalve Molluscs. Wiley, John and Sons, p 99-144

Goulletquer P (1999) Comparative analysis of oxygen consumption rates between cupped oyster spat of Crassostrea gigas of French, Japanese, Spanish and Taiwanese origins. Aquat Living Resour 12:271-277

Goulletquer P, Wolowicz M, Latala A, Geairon P, Huvet A, Boudry P (1999) Comparative analysis of oyxgen consumption rates between cupped oyster spat of Crassostrea gigas of French, Japanese, Spanish and Taiwanese origins. Aquat Living Ressources 12:271-277

Green TJ, Rolland J-L, Vergnes A, Raftos D, Montagnani C (2015) OsHV-1 countermeasures to the Pacific oyster's anti-viral response. Fish Shellfish Immunol 47:435-43

Green TJ, Vergnes A, Montagnani C, Lorgeril J de (2016) Distinct immune responses of juvenile and adult oysters (Crassostrea gigas) to viral and bacterial infections. Vet Res $47: 72$

He Y, Jouaux A, Ford SE, Lelong C, Sourdaine P, Mathieu M, Guo X (2015) Transcriptome analysis reveals strong and complex antiviral response in a mollusc. Fish Shellfish Immunol 46:131-44

Jansen H, Strand Ø, Strohmeier T, Krogness C, Verdegem M, Smaal a (2011) Seasonal variability in nutrient regeneration by mussel Mytilus edulis rope culture in oligotrophic systems. Mar Ecol Prog Ser 431:137-149 
Jansen HM, Strand $\varnothing$, Verdegem M, Smaal A (2012) Accumulation, release and turnover of nutrients (C-N-P-Si) by the blue mussel Mytilus edulis under oligotrophic conditions. $\mathrm{J}$ Exp Mar Bio Ecol 416-417:185-195

Jouaux A, Lafont M, Blin J-L, Houssin M, Mathieu M, Lelong C (2013) Physiological change under OsHV-1 contamination in Pacific oyster Crassostrea gigas through massive mortality events on fields. BMC Genomics 14:590

Justic D, Rabalais NN, Turner RE, Dortch Q (1995) Changes in nutrient structure of riverdominated coastal waters: stochiometric nutrient balance and its consequences. Estuar Coast Shelf Sci 1:339-356

Kasper J, Mumm R, Ruther J (2012) The composition of carcass volatile profiles in relation to storage time and climate conditions. Forensic Sci Int 223:64-71

Lacoste É, Gaertner-Mazouni N (2016) Nutrient regeneration in the water column and at the sediment-water interface in pearl oyster culture (Pinctada margaritifera) in a deep atoll lagoon (Ahe, French Polynesia). Estuar Coast Shelf Sci:1-6

Lomstein BA, Bonne Guldberg L, Hansen J (2006) Decomposition of Mytilus edulis: The effect on sediment nitrogen and carbon cycling. J Exp Mar Bio Ecol 329:251-264

Lyman MG, Enquist LW (2009) Herpesvirus interactions with the host cytoskeleton. J Virol 83:2058-66

Mackin J (1962) Oyster diseases caused by Dermocystidium marinum, and other microorganisms in Louisiana. Publ Inst Mar Sci Univ Texas 7:132-229

Madigan TL, Bott NJ, Torok VA, Percy NJ, Carragher JF, Barros Lopes MA de, Kiermeier A (2014) A microbial spoilage profile of half shell Pacific oysters (Crassostrea gigas) and Sydney rock oysters (Saccostrea glomerata). Food Microbiol 38:219-27

Mazouni N (2004) Influence of suspended oyster cultures on nitrogen regeneration in a coastal lagoon (Thau, Lagoon). Mar Ecol Prog Ser 276:103-113

McKindsey CW, Thetmeyer H, Landry T, Silvert W (2006) Review of recent carrying capacity models for bivalve culture and recommendations for research and management. Aquaculture 261:451-462

Meseck S, Li Y, Dixon M, Rivara K, Wikfors G, Luther G (2012) Effects of a commercial, suspended eastern oyster nursery upon nutrient and sediment chemistry in a temperate, coastal embayment. Aquac Environ Interact 3:65-79

Mineur F, Provan J, Arnott G (2014) Phylogeographical analyses of shellfish viruses: inferring a geographical origin for ostreid herpesviruses OsHV-1 (Malacoherpesviridae). Mar Biol 162:181-192

Minson A, Davison A, Eberle R, Desrosiers RC, Fleckenstein B, D.J. M, Pellet PE, Roizman B, Studdert MJ (2000) Family Herpesviridae. In: Regenmortel MHV van, Fauquet CM, 
Bishop DH., Carstens EB, Estes MK, Lemon SM, Maniloff J, Mayo MA, McGeoch DJ, Pringle CR, Wickner RB (eds) Virus Taxonomy. Seventh Report of the International Comittee on Taxonomy of Viruses. Academic Press, San Diego, California, p 203-225

Moreau P, Moreau K, Segarra A, Tourbiez D, Travers M-A, Rubinsztein DC, Renault T (2015) Autophagy plays an important role in protecting Pacific oysters from OsHV-1 and Vibrio aestuarianus infections. Autophagy 11:516-26

Mostajir B, Roques C, Bouvier C, Bouvier T, Fouilland É, Got P, Floc'h E Le, Nouguier J, Mas S, Sempéré R, Sime-Ngando T, Troussellier M, Vidussi F (2015) Microbial food web structural and functional responses to oyster and fish as top predators. Mar Ecol Prog Ser 535:11-27

Newell RIE (1985) Physiological, effects of the MSX parasite Haplosporidium nelsoni (Haskin, Stauber \& Mackin) on the American oyster Crassostrea vriginica (Gmelin). J Shellfish Res 5:91-95

Nicolas J-L, Comps M, Cochennec N (1992) Herpes-like virus infecting pacific-oyster larvae Crassostrea gigas. Bull Eur Ass Fi 12:11-13

Paul-Pont I, Dhand NK, Whittington RJ (2013) Influence of husbandry practices on OsHV-1 associated mortality of Pacific oysters Crassostrea gigas. Aquaculture 412-413:202-214

Paul-Pont I, Evans O, Dhand NK, Whittington RJ (2015) Experimental infections of Pacific oyster Crassostrea gigas using the Australian ostreid herpesvirus-1 (OsHV-1) $\mu$ Var strain. Dis Aquat Organ 113:137-47

Peñuelas J, Poulter B, Sardans J, Ciais P, Velde M van der, Bopp L, Boucher O, Godderis Y, Hinsinger P, Llusia J, Nardin E, Vicca S, Obersteiner M, Janssens I a (2013) Humaninduced nitrogen-phosphorus imbalances alter natural and managed ecosystems across the globe. Nat Commun 4:2934

Pepin JF, Riou a, Renault T (2008) Rapid and sensitive detection of ostreid herpesvirus 1 in oyster samples by real-time PCR. J Virol Methods 149:269-76

Pernet F, Barret J, Gall P Le, Corporeau C, Dégremont L, Lagarde F, Pépin J, Keck N (2012) Mass mortalities of Pacific oysters Crassostrea gigas reflect infectious diseases and vary with farming practices in the Mediterranean Thau lagoon, France. Aquac Environ Interact 2:215-237

Pernet F, Barret J, Marty C, Moal J, Gall P Le, Boudry P (2010) Environmental anomalies, energetic reserves and fatty acid modifications in oysters coincide with an exceptional mortality event. Mar Ecol Prog Ser 401:129-146

Pernet F, Lagarde F, Gall P Le, Roque D’Orbcastel E (2014) Associations between farming practices and disease mortality of Pacific oyster Crassostrea gigas in a Mediterranean lagoon. Aquac Environ Interact 5:99-106 
Pernet F, Lagarde F, Jeannée N, Daigle G, Barret J, Gall P Le, Quere C, D’orbcastel ER (2014) Spatial and temporal dynamics of mass mortalities in oysters is influenced by energetic reserves and food quality. PLoS One 9:e88469

Petton B, Boudry P, Alunno-Bruscia M, Pernet F (2015) Factors influencing disease-induced mortality of Pacific oysters Crassostrea gigas. Aquac Environ Interact 6:205-222

Petton B, Bruto M, James A, Labreuche Y, Alunno-Bruscia M, Roux F Le (2015) Crassostrea gigas mortality in France: the usual suspect, a herpes virus, may not be the killer in this polymicrobial opportunistic disease. Front Microbiol 6:686

Pouvreau S, Jonquières G, Buestel D (1999) Filtration by the pearl oyster, Pinctada margaritifera, under conditions of low seston load and small particle size in a tropical lagoon habitat. Aquaculture 176:295-314

Redfield AC, Ketchum PH, Richards FA (1963) The influence of organisms on the composition of seawater. In: Hill MN (ed) The Sea. Wiley, London, p 26-77

Renault T, Bouquet AL, Maurice J-T, Lupo C, Blachier P (2014) Ostreid herpesvirus 1 infection among Pacific oyster (Crassostrea gigas) Spat: relevance of water temperature to virus replication and circulation prior to the onset of mortality. Appl Environ Microbiol 80:5419-26

Renault T, Cochennec N, Deuff R-M Le, Chollet B (1994) Herpes-like virus infecting Japanese oyster (Crassostrea gigas) spat. Bull Eur Assoc Fish Pathol 14:64

Renault T, Deuff R Le, Chollet B, Cochennec N (2000) Concomitant herpes-like virus infections in hatchery-reared larvae and nursery-cultured spat Crassostrea gigas and Ostrea edulis. 42:173-183

Renault T, Deuff R Le, Delsert C (2000) Development of a PCR procedure for the detection of a herpes-like virus infecting oysters in France. J Virol Methods 88:41-50

Richard M, Archambault P, Thouzeau G, Desrosiers G (2006) Influence of suspended mussel lines on the biogeochemical fluxes in adjacent water in the Îles-de-la-Madeleine (Quebec, Canada). Can J Fish Aquat Sci 63:1198-1213

Richard M, Archambault P, Thouzeau G, McKindsey CW, Desrosiers G (2007) Influence of suspended scallop cages and mussel lines on pelagic and benthic biogeochemical fluxes in Havre-aux-Maisons Lagoon, Îles-de-la-Madeleine (Quebec, Canada). Can J Fish Aquat Sci 64:1491-1505

Robert P, McKindsey CW, Chaillou G, Archambault P (2013) Dose-dependent response of a benthic system to biodeposition from suspended blue mussel (Mytilus edulis) culture. Mar Pollut Bull 66:92-104

Sauvage C, Pépin JF, Lapègue S, Boudry P, Renault T (2009) Ostreid herpes virus 1 infection in families of the Pacific oyster, Crassostrea gigas, during a summer mortality outbreak: 
differences in viral DNA detection and quantification using real-time PCR. Virus Res 142:181-7

Schikorski D, Faury N, Pepin JF, Saulnier D, Tourbiez D, Renault T (2011) Experimental ostreid herpesvirus 1 infection of the Pacific oyster Crassostrea gigas: kinetics of virus DNA detection by q-PCR in seawater and in oyster samples. Virus Res 155:28-34

Schikorski D, Renault T, Saulnier D, Faury N, Moreau P, Pépin J (2011) Experimental infection of Pacific oyster Crassostrea gigas spat by ostreid herpesvirus 1: demonstration of oyster spat susceptibility. Vet Res 42:27

Segarra A, Baillon L, Faury N, Tourbiez D, Renault T (2016) Detection and distribution of ostreid herpesvirus 1 in experimentally infected Pacific oyster spat. J Invertebr Pathol 133:59-65

Segarra A, Faury N, Pépin J-F, Renault T (2014) Transcriptomic study of 39 ostreid herpesvirus 1 genes during an experimental infection. J Invertebr Pathol 119:5-11

Segarra A, Pépin JF, Arzul I, Morga B, Faury N, Renault T (2010) Detection and description of a particular Ostreid herpesvirus 1 genotype associated with massive mortality outbreaks of Pacific oysters, Crassostrea gigas, in France in 2008. Virus Res 153:92-9

Smaal a. C, Schellekens T, Stralen MR van, Kromkamp JC (2013) Decrease of the carrying capacity of the Oosterschelde estuary (SW Delta, NL) for bivalve filter feeders due to overgrazing? Aquaculture 404-405:28-34

Soletchnik P, Goulletquer P, Cochennec N, Renault T, Geairon P (1998) Ecophysiological study on the Pacific oyster Crassostrea gigas naturally infected by a Chlamydia-like microorganism : effect of infection level and diet on oyster physiological responses. Haliottis 27:1-19

Soletchnik P, Razet D, Geairon P, Faury N, Goulletquer P (1997) Ecophysiologie de la maturation sexuelle et de la ponte de l'huître creuse Crassostrea gigas: réponses métaboliques (respiration) et alimentaires (filtration, absorption) en fonction des différents stades de maturation. Aquat Living Ressources 10:177-185

Souchu P, Vaquer A, Collos Y, Landrein S, Bibent B (2011) Influence of shellfish farming activities on the biogeochemical composition of the water column in Thau lagoon. 218:141-152

Souchu P, Vaquer A, Collos Y, Landrein S, Deslous-paoli J-M, Bibent B (2001) Influence of shellfish farming activities on the biogeochemical composition of the water column in Thau lagoon. Mar Ecol Prog Ser 218:141-252

Stroud EM, Connell CPO, Rice PH, Snow NH, Barnes BB, Elshaer MR, Hanson JE (2013) Chemical shark repellent : Myth or fact? The effect of a shark necromone on shark feeding behavior. Ocean Coast Manag:1-8 
Suquet M, Kermoysan G De, Gonzalez Araya R, Queau I, Lebrun L, Souchu P Le, Mingant C (2009) Anesthesia in Pacific oyster , Crassostrea gigas. Aquat Living Ressourcesources 22:29-34

Tamayo D, Corporeau C, Petton B, Quere C, Pernet F (2014) Physiological changes in Pacific oyster Crassostrea gigas exposed to the herpesvirus OsHV-1 $\mu$ Var. Aquaculture 432:304310

Tran D, Haberkorn H, Soudant P, Ciret P, Massabuau J-C (2010) Behavioral responses of Crassostrea gigas exposed to the harmful algae Alexandrium minutum. Aquaculture 298:338-345

Trottet A, Roy S, Tamigneaux E, Lovejoy C, Tremblay R (2008) Impact of suspended mussels (Mytilus edulis L.) on plankton communities in a Magdalen Islands lagoon (Québec, Canada): A mesocosm approach. J Exp Mar Bio Ecol 365:103-115

Tsiola a, Pitta P, Fodelianakis S, Pete R, Magiopoulos I, Mara P, Psarra S, Tanaka T, Mostajir B (2016) Nutrient Limitation in Surface Waters of the Oligotrophic Eastern Mediterranean Sea: an Enrichment Microcosm Experiment. Microb Ecol 71:575-88

Wan-soo K, Seong-Jim Y, Yoon K, Sung-Yeon K (2002) Endogenous Rythm in oxygen consumption by the Pacific Oyster Crassostrea gigas. J Fish Sci Technol 5:191-199

West EJ, Welsh DT, Pitt KA (2009) Influence of decomposing jellyfish on the sediment oxygen demand and nutrient dynamics. Jellyfish Bloom 616:151-160

Whittington RJ, Dhand NK, Evans O, Paul-Pont I (2015) Further observations on the influence of husbandry practices on OsHV-1 $\mu$ Var mortality in Pacific oysters Crassostrea gigas: Age, cultivation structures and growing height. Aquaculture 438:8297

Willson LL, Burnett LE (2000) Whole animal and gill tissue oxygen uptake in the Eastern oyster, Crassostrea virginica : Effects of hypoxia, hypercapnia, air exposure, and infection with the protozoan parasite Perkinsus marinus 1. 246:223-240 


\section{FIGURE CAPTIONS}

Figure 1: Diagram of the experimental design, composed of 3 infection treatments (C: control, L1, L2: Loads 1 and 2 corresponding to $0,10^{8}$ and $10^{9}$ viral DNA copies.ind ${ }^{-1}$ ), 6 dates (d-5, $\mathrm{d} 1, \mathrm{~d} 3, \mathrm{~d} 7, \mathrm{~d} 10, \mathrm{~d} 14$ after inoculum injection) and 4 incubation treatments, including a water treatment $(\mathrm{W})$. All levels of treatments were replicated three times.

Figure 2: Mean $( \pm \mathrm{SE})$ cumulative mortality $(\%)$ observed according to dates and infection treatments (C: control, L1, L2: Load 1 and 2). Stars indicate significant differences among treatments L1, L2 and C.

Figure 3: Mean $\left( \pm\right.$ SE) number of viral DNA copies $\left(\log 10 \mathrm{C} 9 \mathrm{C} 10\right.$. totalDNA.ng $\left.^{-1}\right)$ quantified A) in flesh of live oysters according to dates (d1, d3, d7, d10, d14) and infection treatments (C: control, L1, L2: Load 1 and 2), B) in oyster flesh according to status (C: control, L: infected, D: dead). Stars indicate significant differences among treatments L1, L2 and C. Means linked with a horizontal line do not differ from one another within the same date. Different letters indicate significant differences among statuses.

Figure 4: Number of dead oysters incubated in metabolic chambers according to dates (d1, d3, d7, d10, d14) and infection treatments (C: control, L1, L2: Load 1 and 2). A total of 9 individuals were incubated with the same incubation treatment for each same date.

Figure 5: Mean $( \pm \mathrm{SE})$ of $\mathrm{A}) \mathrm{O}_{2}$ consumption, B) $\mathrm{NH}_{4}$, and C) $\mathrm{PO}_{4}$ fluxes, according to dates (d1, d3, d7, d10, d14) and incubation treatments (W: water, C: control oysters, L1, L2: infected oysters) considering fluxes at the interface of live and dead oysters. Stars indicate significant differences in absence of oysters (W vs. C, L1, L2). Means linked with a horizontal line do not differ from one another within the same date and were different from other means. 
Figure 6: Mean ( \pm SE) of A) $\mathrm{O}_{2}$ consumption, B) $\mathrm{NH}_{4}$ and C) $\mathrm{PO}_{4}$ fluxes, D) $\mathrm{NH}_{4} / \mathrm{PO}_{4}$ ratio at Final time of incubation (Tf), measured according to status (W: water, C: Control oysters, L: pool of L1 and L2 infected oysters, D: dead oysters) regardless of date. Different letters indicate significant differences among statuses.

Figure 7: Comparison of mortality kinetics (\%) of oyster juvenile observed in this study with those observed in classical epidemiological studies and in situ observations made in the Thau Lagoon. 


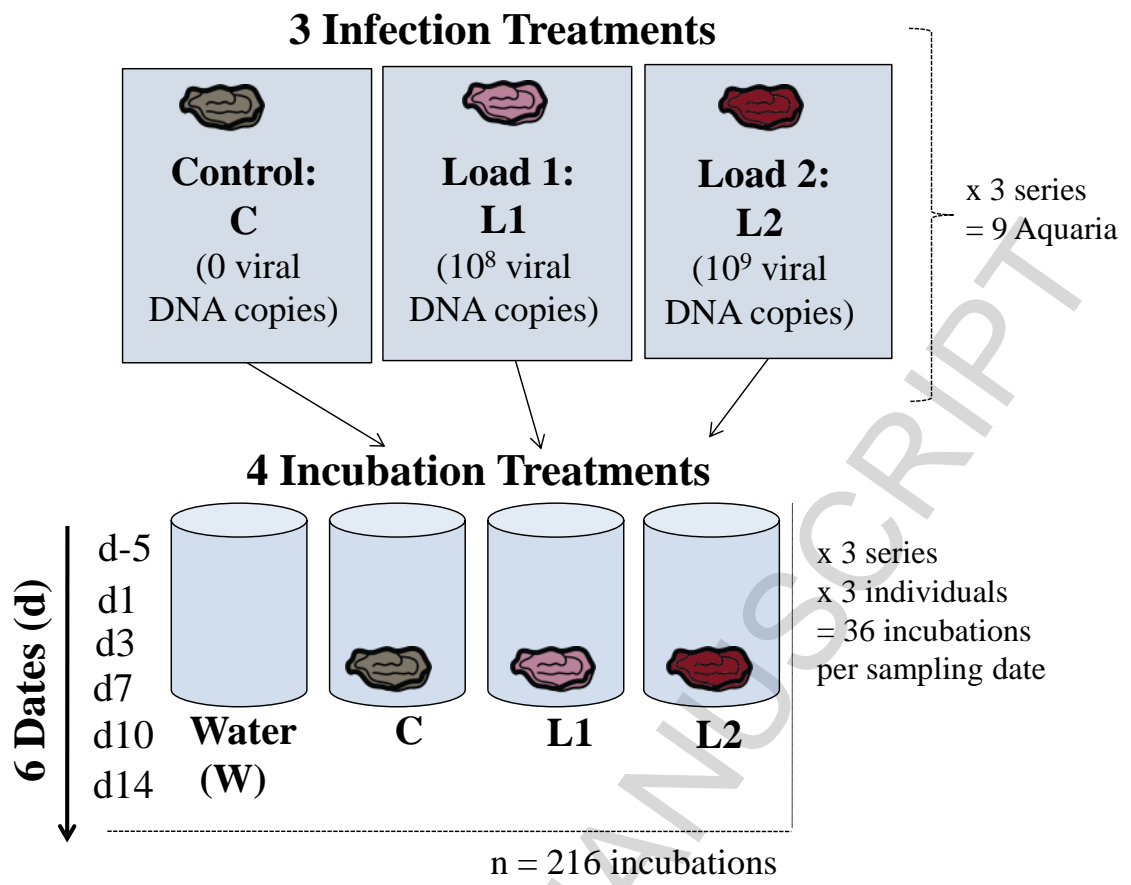

Figure 1. Richard et al. 


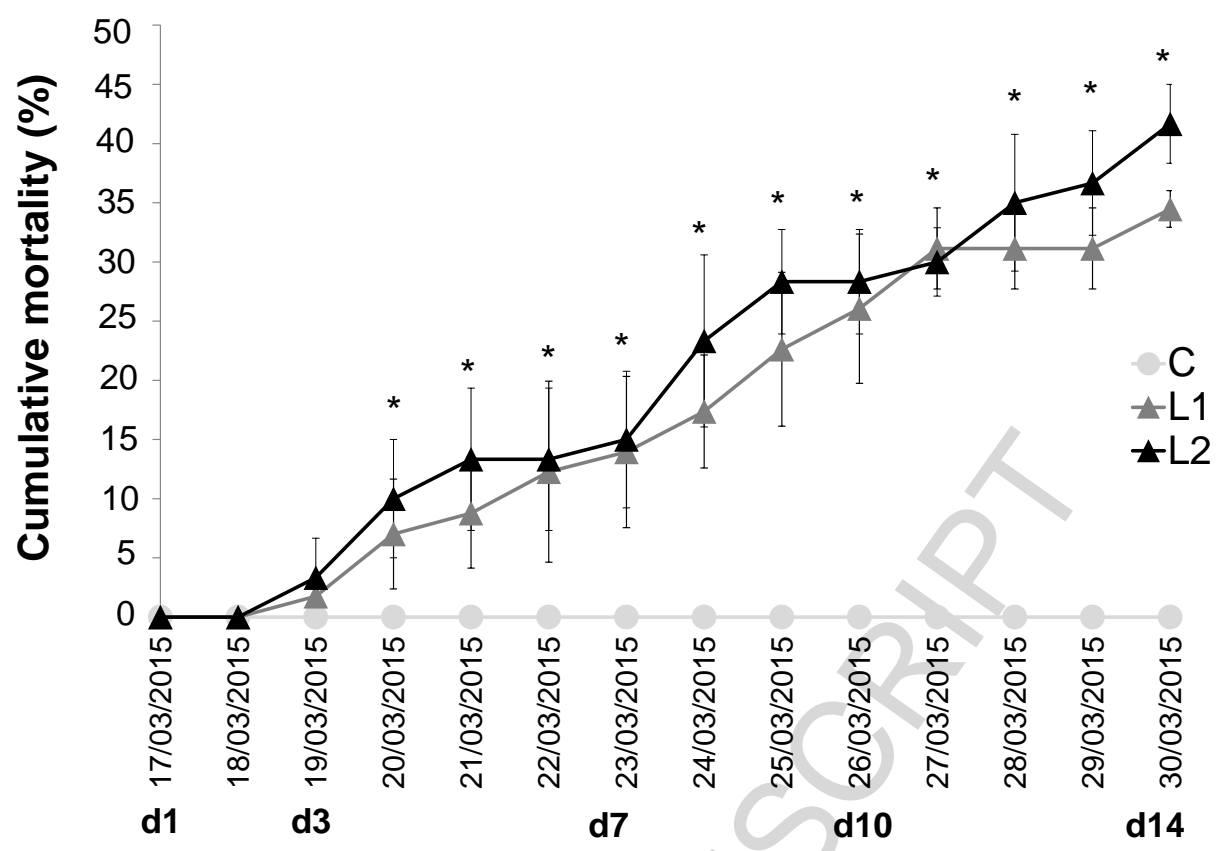

Figure 2. Richard et al. 

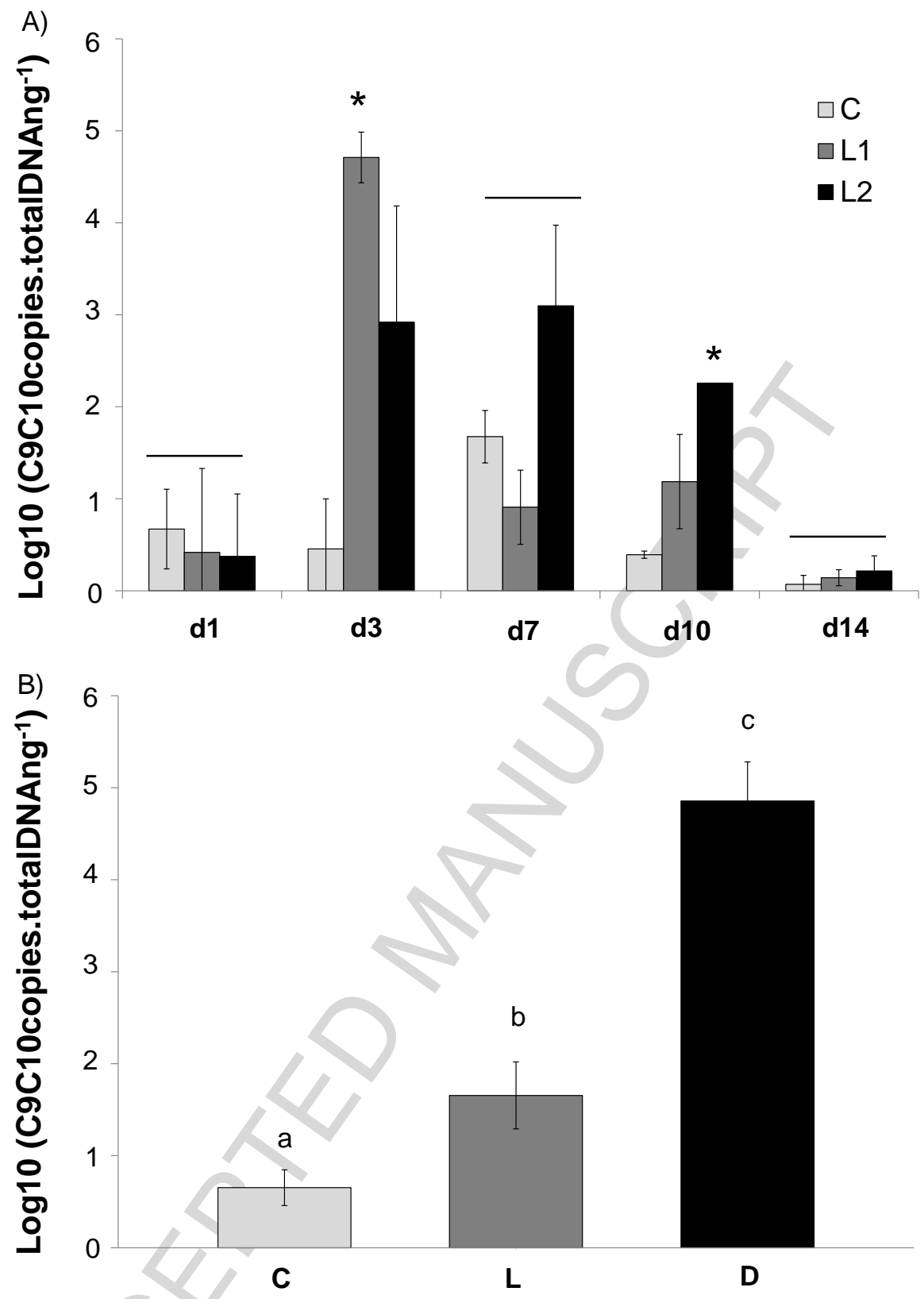

Figure 3. Richard et al. 


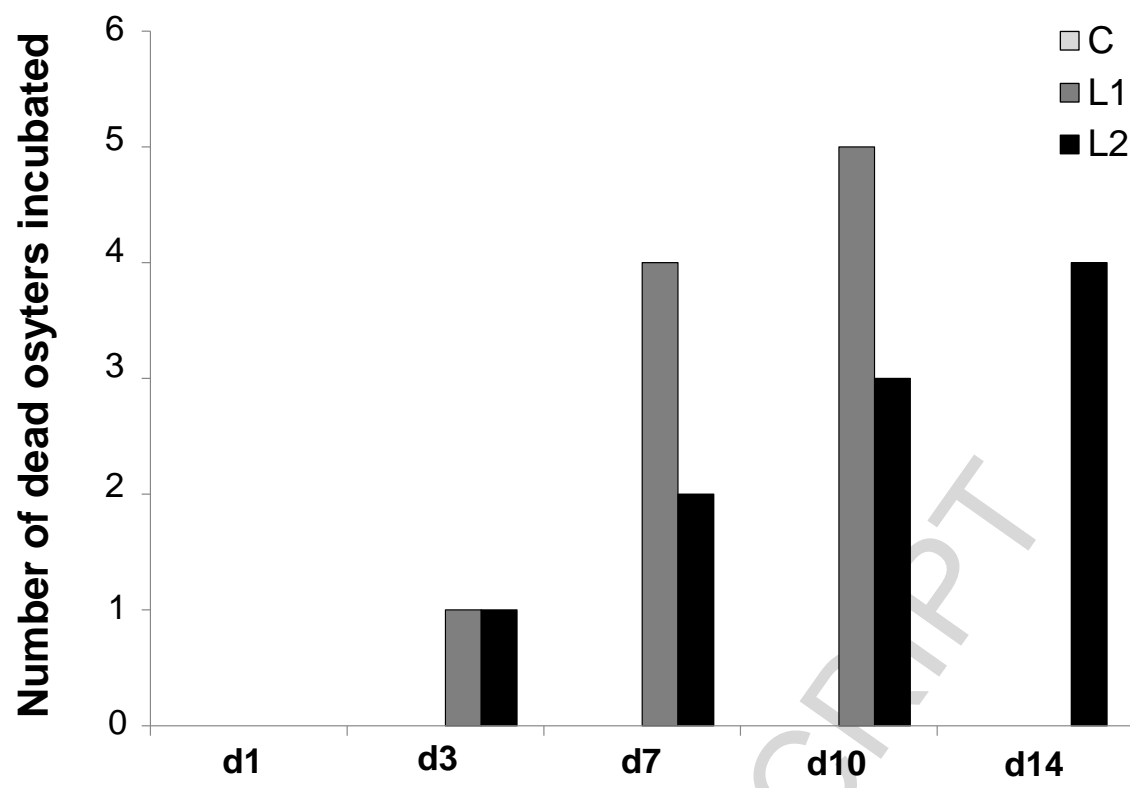

Figure 4. Richard et al. 

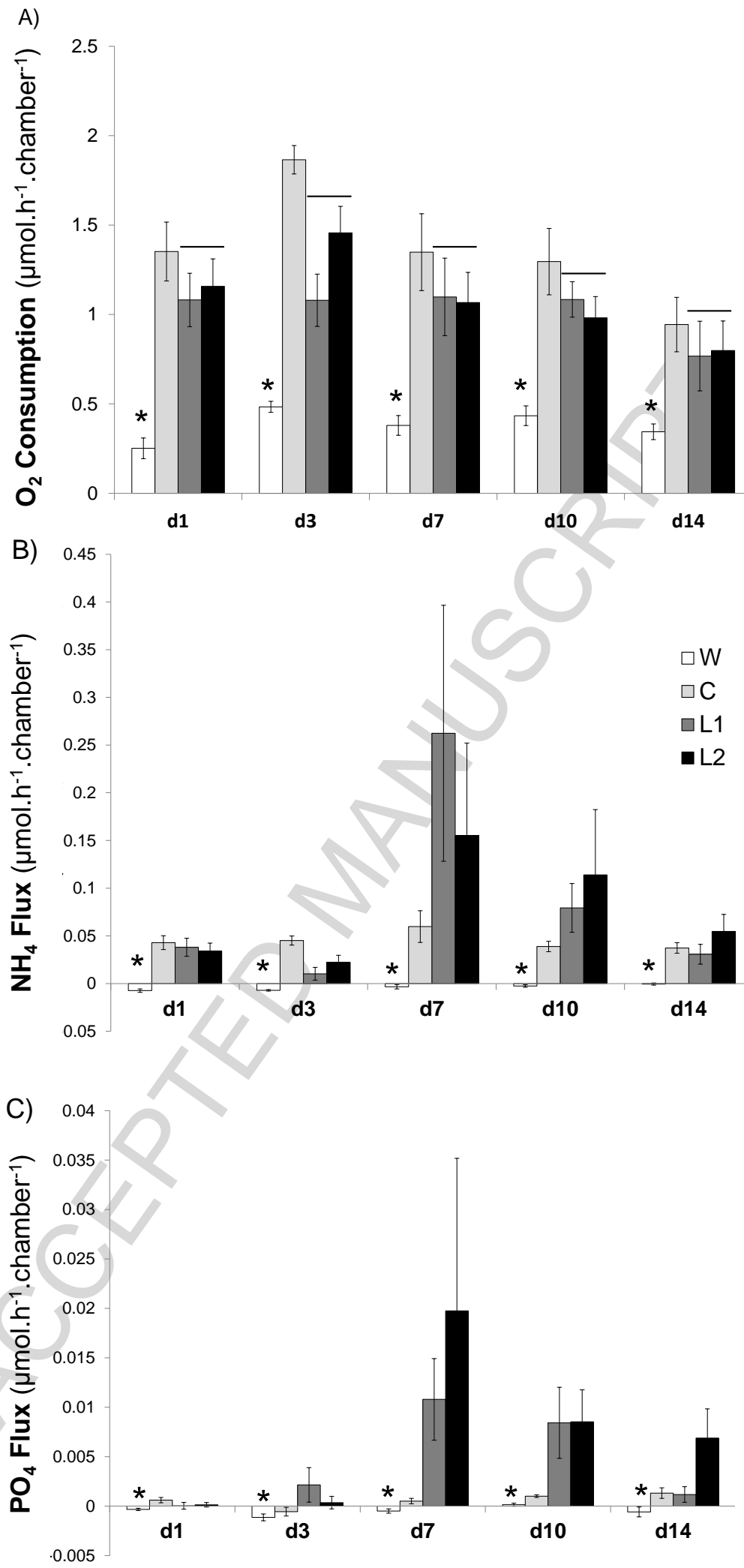

Figure 5. Richard et al. 


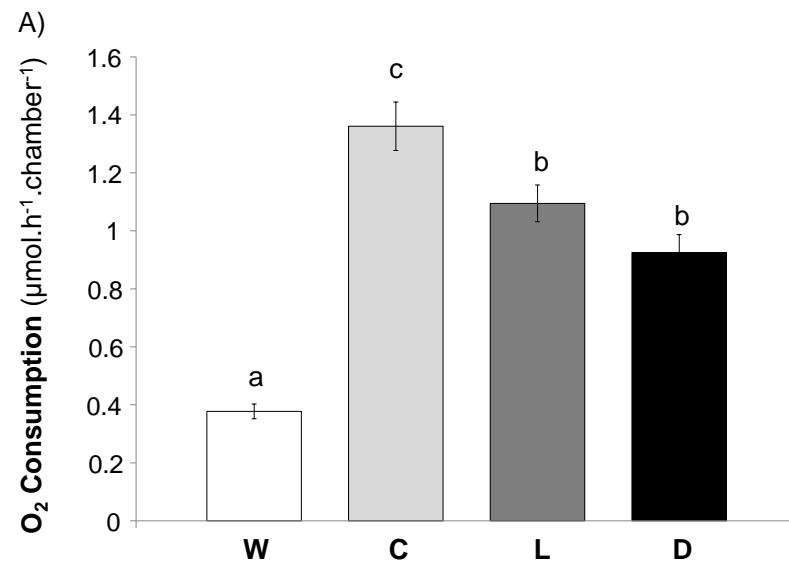

C)

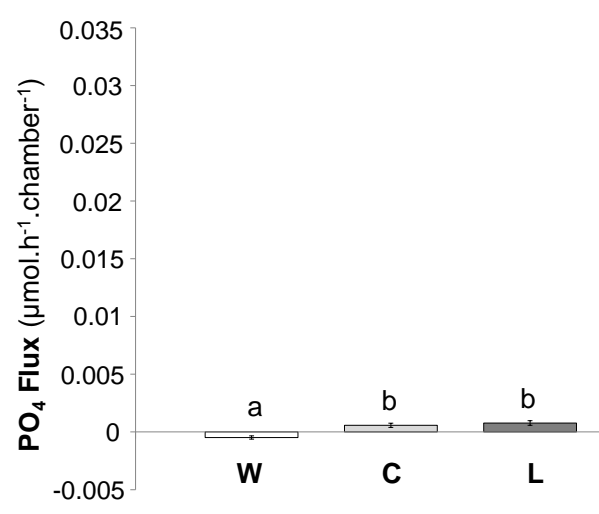

B)
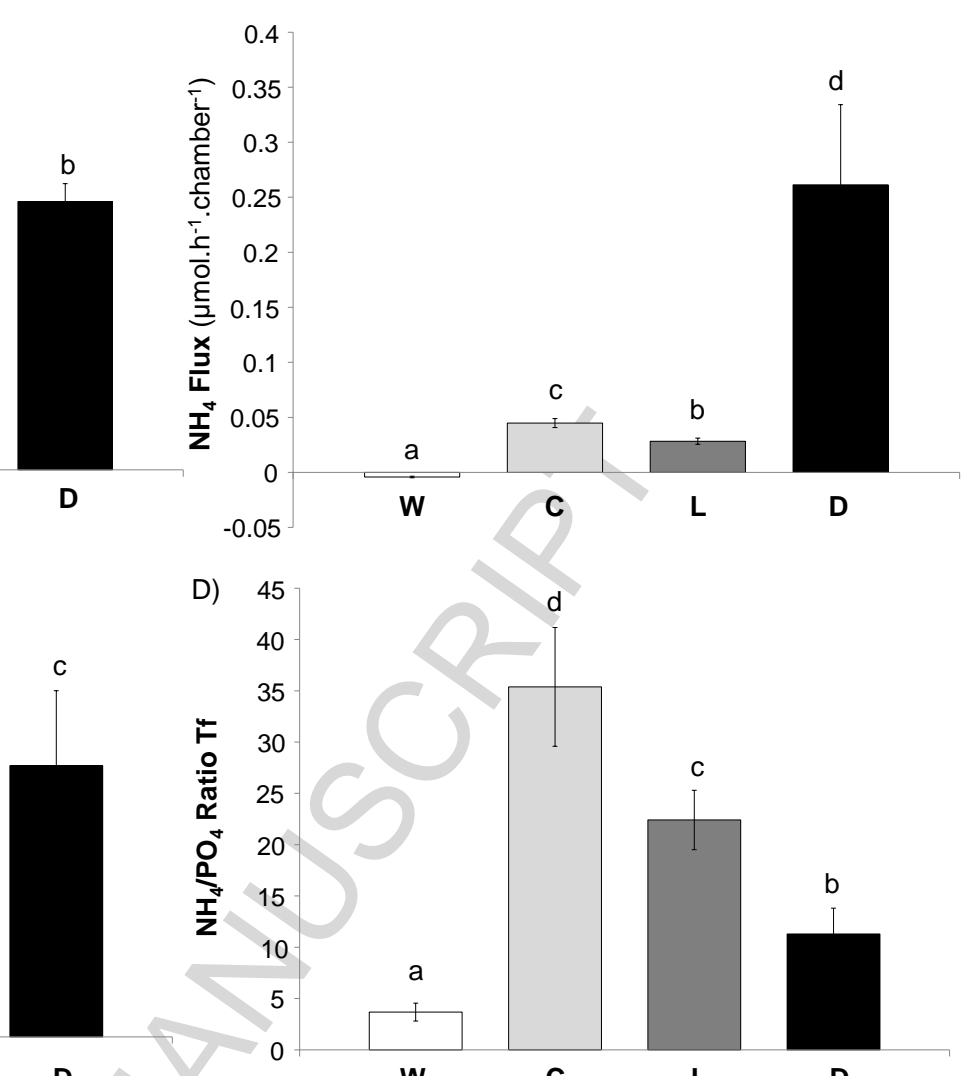

D
D) 45

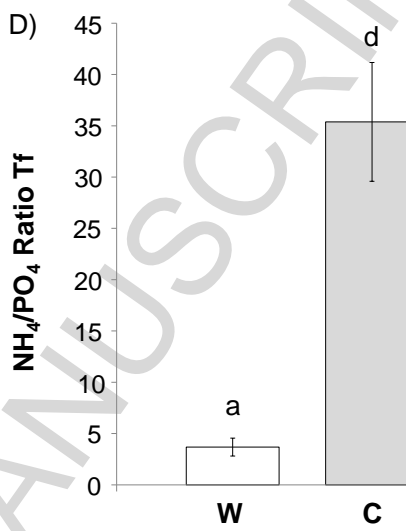

w

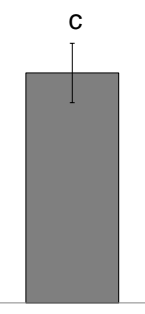

$\mathbf{L}$

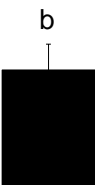

D

Figure 6. Richard et al. 
Juvenile oyster mortality influence on fluxes

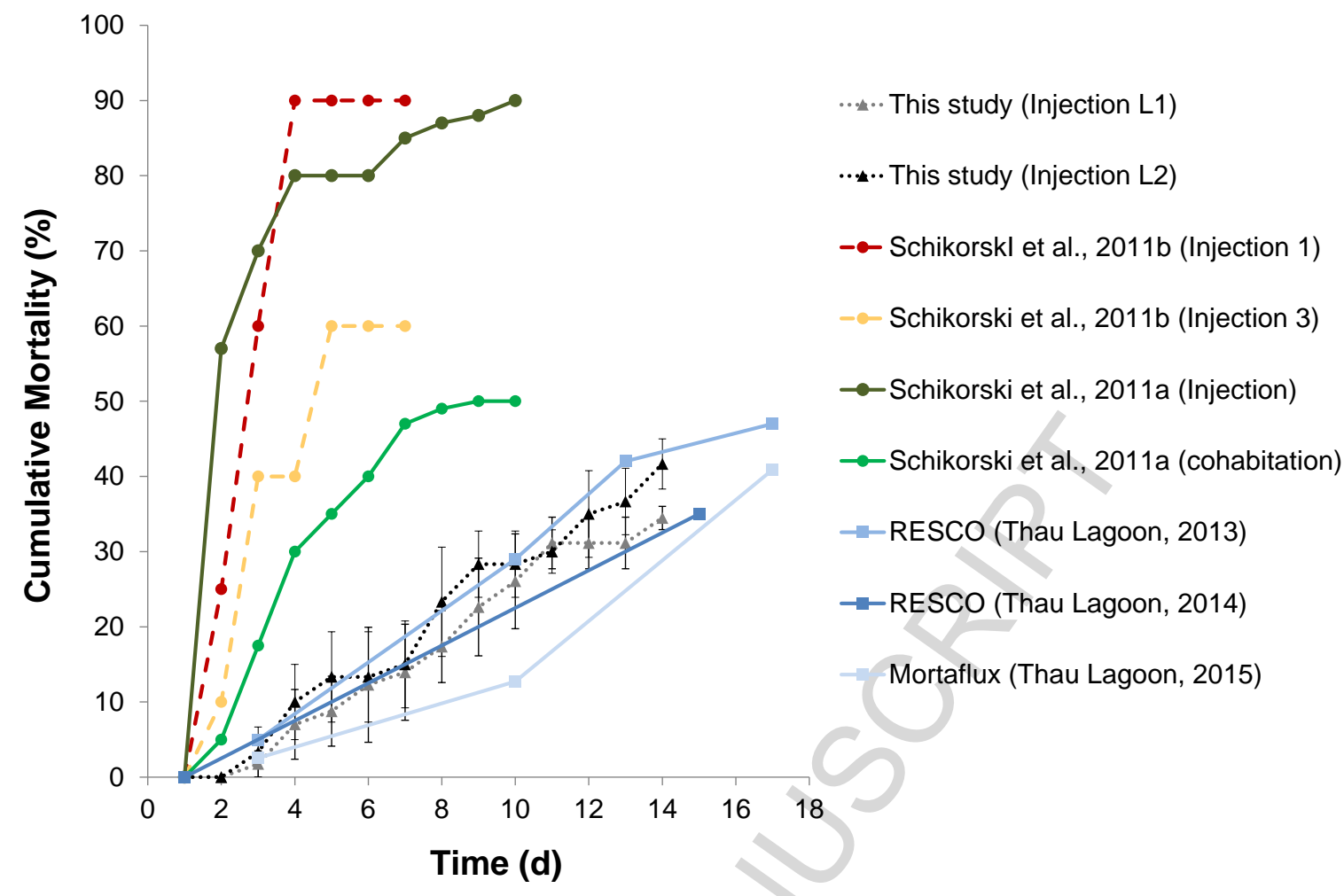

Figure 7. Richard et al. 


\section{TABLES}

Table 1: Results of PERMANOVAs and a posteriori tests performed on length; total, shell and flesh weight; AFNOR; oxygen $\left(\mathrm{O}_{2}\right)$ consumption; and ammonium $\left(\mathrm{NH}_{4}\right)$ and phosphate $\left(\mathrm{PO}_{4}\right)$ fluxes to test the effect of treatment (TR: W, C, L1, L2) at d-5 (i.e. 5 days before injection) to confirm that there was no initial effect of aquarium or pre-assigned batch $(\mathrm{C}, \mathrm{L} 1$, L2) on oyster weight and metabolism before the viral inoculum injection. Df: degree of freedom, SS: Sums of squares, Res: Residual

\begin{tabular}{|c|c|c|c|c|c|c|c|}
\hline Variables & Source & df & SS & MS & $\begin{array}{c}\text { Pseudo- } \\
\text { F }\end{array}$ & p (Perm) & $\begin{array}{c}\text { a posteriori } \\
\text { test }\end{array}$ \\
\hline \multirow[t]{3}{*}{ Length } & TR & 2 & 0.26 & 0.13 & 0.09 & 0.92 & \\
\hline & Res & 24 & 33.01 & 1.38 & & & \\
\hline & Total & 26 & 33.27 & & & & \\
\hline \multirow[t]{3}{*}{ Total Weight } & $\mathrm{TR}$ & 2 & 0.00 & 0.00142 & 1.13 & 0.344 & \\
\hline & Res & 24 & 0.03 & 0.00126 & & & \\
\hline & Total & 26 & 0.03 & & & & \\
\hline \multirow[t]{3}{*}{ Shell Weight } & $\mathrm{TR}$ & 2 & 0.00 & 0.00069 & 0.72 & 0.484 & \\
\hline & Res & 24 & 0.02 & 0.00095 & & & \\
\hline & Total & & 0.02 & & & & \\
\hline \multirow[t]{3}{*}{ Flesh Weight } & $\mathrm{TR}$ & 2 & 0.00 & $7.70 \mathrm{E}-06$ & 0.02 & 0.981 & \\
\hline & Res & 24 & 0.01 & $5.08 \mathrm{E}-04$ & & & \\
\hline & Total & 26 & 0.01 & & & & \\
\hline \multirow[t]{3}{*}{ AFNOR } & & 2 & 0.21 & 0.10 & 0.02 & 0.98 & \\
\hline & Res & 24 & 100.85 & 4.20 & & & \\
\hline & Total & 26 & 101.06 & & & & \\
\hline \multirow[t]{3}{*}{$\mathrm{O}_{2}$ Consumption } & $\mathrm{TR}$ & 3 & 14.57 & 4.86 & 52.05 & 0.001 & $\mathrm{~W}<\mathrm{C}, \mathrm{L} 1, \mathrm{~L} 2$ \\
\hline & Res & 29 & 2.71 & 0.09 & & & \\
\hline & Total & 32 & 17.27 & & & & \\
\hline \multirow[t]{3}{*}{$\mathrm{NH}_{4}$ Fluxes } & $\mathrm{TR}$ & 3 & 0.02 & 0.00536 & 9.17 & 0.001 & $\mathrm{~W}<\mathrm{C}, \mathrm{L} 1, \mathrm{~L} 2$ \\
\hline & Res & 30 & 0.02 & 0.00058 & & & \\
\hline & Total & 33 & 0.03 & & & & \\
\hline
\end{tabular}


Juvenile oyster mortality influence on fluxes

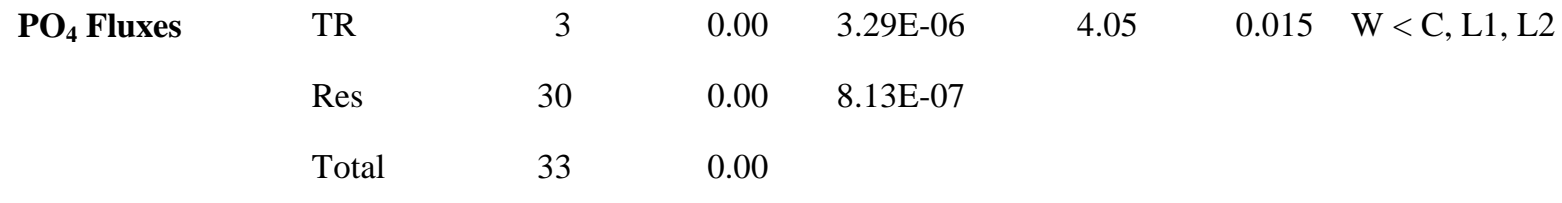

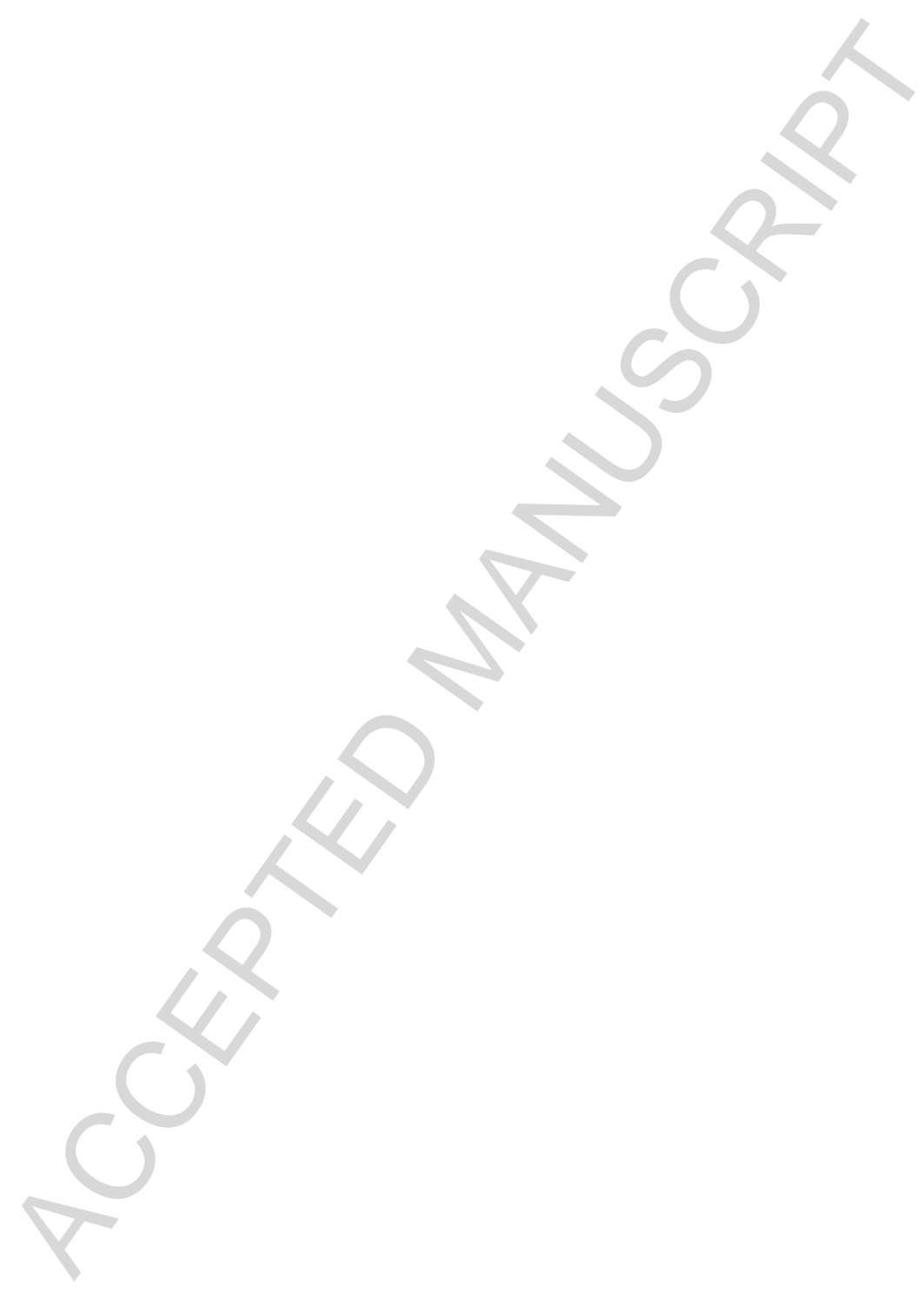


Table 2: Results of PERMANOVAs and a posteriori tests performed on oxygen $\left(\mathrm{O}_{2}\right)$ consumption, and ammonium $\left(\mathrm{NH}_{4}\right)$ and phosphate $\left(\mathrm{PO}_{4}\right)$ fluxes to test the effect of date (Da: d1, d3, d7, d10, d14), treatment (TR: W, C, L1, L2) and their interaction (Da $\times$ TR), considering fluxes observed at the interface of dead oysters in the dataset. df: degrees of freedom, SS: sums of squares, Res: Residual

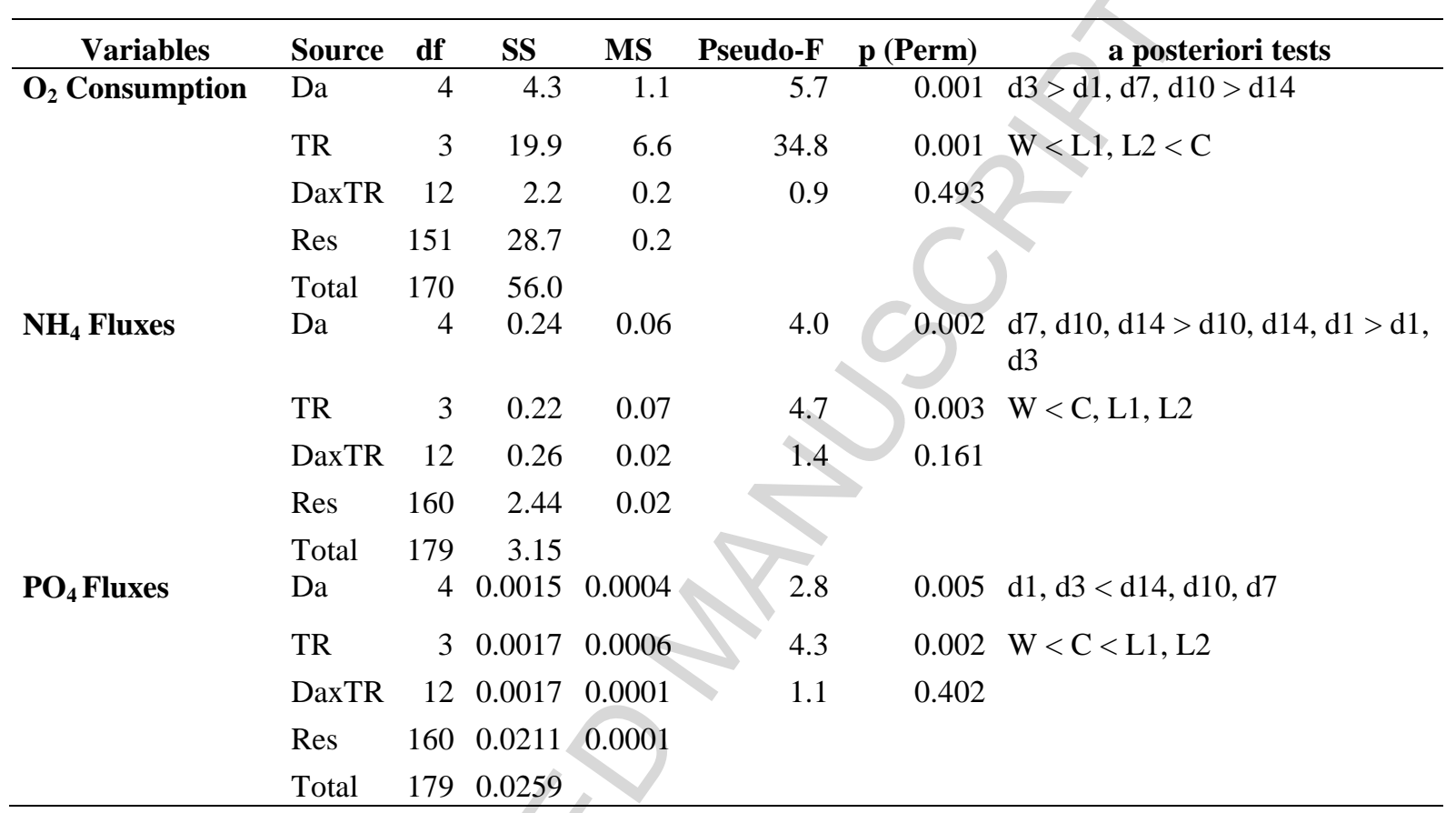


Table 3: Results of PERMANOVAs and a posteriori tests performed on oxygen $\left(\mathrm{O}_{2}\right)$ consumption, and ammonium $\left(\mathrm{NH}_{4}\right)$ phosphate $\left(\mathrm{PO}_{4}\right)$ fluxes, and $\mathrm{NH} 4 / \mathrm{PO} 4$ ratio at $\mathrm{Tf}$ (final sampling time) to test the effect of status (St: W: water, C: control oysters, L: pooled L1 and L2 infected oyster, D: dead oysters). df: degrees of freedom, SS: sums of squares, Res: residual

\begin{tabular}{|c|c|c|c|c|c|c|c|}
\hline Variables & Source & df & SS & $M S$ & Pseudo-F & $\mathbf{P}($ perm $)$ & a posteriori tests \\
\hline \multirow[t]{3}{*}{$\mathrm{O}_{2}$ Consumption } & St & 3 & 20.548 & 6.8495 & 32.3 & 0.001 & $\mathrm{~W}<\mathrm{D}, \mathrm{L}<\mathrm{C}$ \\
\hline & Res & 167 & 35.407 & 0.21202 & & & \\
\hline & Total & 170 & 55.955 & & & & \\
\hline \multirow[t]{3}{*}{$\mathrm{NH}_{4}$ Fluxes } & Status & 3 & 1.0592 & 0.35306 & & 0.001 & $\mathrm{~W}<\mathrm{L}<\mathrm{C}<\mathrm{D}$ \\
\hline & Res & 176 & 2.0925 & 0.011889 & & & \\
\hline & Total & 179 & 3.1517 & & & & \\
\hline \multirow[t]{3}{*}{$\mathrm{PO}_{4}$ Fluxes } & St & 3 & 0.0095553 & 0.0031851 & & 0.001 & $\mathrm{~W}<\mathrm{C}, \mathrm{L}<\mathrm{D}$ \\
\hline & Res & 176 & 0.016331 & $9.28 \mathrm{E}-05$ & & & \\
\hline & Total & 179 & 0.025886 & & & & \\
\hline \multirow[t]{3}{*}{$\mathrm{NH}_{4} / \mathrm{PO}_{4} \mathrm{Tf}$} & St & 3 & 21971 & 7323.8 & 11.1 & 0.001 & $\mathrm{~W}<\mathrm{D}<\mathrm{L}<\mathrm{C}$ \\
\hline & Res & 167 & $1.10 \mathrm{E}+05$ & 659.54 & & & \\
\hline & Total & 170 & $1.32 \mathrm{E}+05$ & 1 & & & \\
\hline
\end{tabular}


Juvenile oyster mortality influence on fluxes

Table 4: Non exhaustive review of oxygen consumption and ammonia excretion rates measured for several species of oysters. For conversion, we considered the formula of Bayne et al. (1987) $\mathrm{Ys}=(\mathrm{Ws} / \mathrm{We})^{\mathrm{b}} \times \mathrm{Ye}$, where Ys is the physiological rate for an individual of standard dry weight, Ws is the standard weight $(1 \mathrm{~g})$. We is the weight of the animal $(\mathrm{g})$, Ye is the uncorrected measured physiological rate and $\mathrm{b}$ the weight exponent for the physiological rate function. $\mathrm{b}=0.8$ for respiration according Bougrier et al. (1995). Note that 1 mol $\mathrm{O}_{2}=22.4 \mathrm{~L}=32 \mathrm{~g}$. Finally, our data were converted into DW assuming that mean weight of juvenile of this study was $158 \mathrm{WWmg}$ corresponding to $20.54 \mathrm{DWmg}$ considering the equation DW =

$0.13 \mathrm{~g} \mathrm{WW}(\mathrm{n}=30$ : this study, data not shown).

\begin{tabular}{|c|c|c|c|c|c|c|c|}
\hline $\mathrm{O}_{2}$ consumption & $\begin{array}{c}\text { Conversion in } \\
\left(\mu \mathrm{molO}_{2} \cdot \mathrm{gDW}\right. \\
\left.{ }_{1} \cdot \mathrm{h}_{-1}\right)\end{array}$ & NH4 excretion & 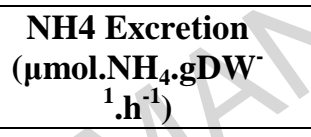 & Species & Temp $\left({ }^{\circ} \mathrm{C}\right)$ & Stage & References \\
\hline $0.987 \mathrm{mlO}_{2} \cdot \mathrm{gDW}^{-1} \cdot \mathrm{h}^{-1}$ & 41.13 & $5.542 \mu \mathrm{gNH}_{4} \cdot \mathrm{gDW}^{-1} \cdot \mathrm{h}^{-1}$ & 0.40 & $\begin{array}{l}\text { Crassostrea } \\
\text { virginica }\end{array}$ & nd & Adult & Gale et al. (1991) \\
\hline $0.33 \mathrm{mlO}_{2} \cdot \mathrm{gDW}^{-1} \cdot \mathrm{h}^{-1}$ & 13.75 & & - & $\begin{array}{c}\text { Crassostrea } \\
\text { virginica }\end{array}$ & 20 & Adult & Newell (1985) \\
\hline $371.5 \mu \mathrm{lO}_{2} \cdot \mathrm{gDW}^{-1} \cdot \mathrm{h}^{-1}$ & 16.58 & & - & $\begin{array}{c}\text { Crassostrea } \\
\text { virginica }\end{array}$ & 20 & $\begin{array}{c}\text { Spat, } \\
\text { juvenile } \\
\text { and } \\
\text { adult }\end{array}$ & Dame (1972) \\
\hline $0.51 \mathrm{mlO}_{2} \cdot \mathrm{gDW}^{-1} \cdot \mathrm{h}^{-1}$ & 22.77 & & - & $\begin{array}{l}\text { Crassostrea } \\
\text { gigas }\end{array}$ & Ambient & & Bernard \& Noakes (1990) \\
\hline $1.02 \mathrm{mlO}_{2} \cdot \mathrm{gDW}^{-1} \cdot \mathrm{h}^{-1}$ & 45.54 & - & - & $\begin{array}{l}\text { Crassostrea } \\
\text { gigas }\end{array}$ & $22-23$ & Adult & Wan-Soo et al. (2002) \\
\hline $0.7 \mathrm{mlO}_{2} \cdot \mathrm{gDW}^{-1} \cdot \mathrm{h}^{-1}$ & 31.25 & - & - & $\begin{array}{l}\text { Crassostrea } \\
\text { gigas }\end{array}$ & $22-23$ & Adult & Wan-Soo et al. (2002) \\
\hline $1.022 \mathrm{mgO}_{2} \cdot \mathrm{gDW}^{-1} \cdot \mathrm{h}^{-1}$ & 31.94 & - & - & $\begin{array}{l}\text { Crassostrea } \\
\text { gigas }\end{array}$ & $20-22$ & Adult & Soletchnik et al. (1997) \\
\hline $0.860 \mathrm{mgO}_{2} \cdot \mathrm{gDW}^{-1} \cdot \mathrm{h}^{-1}$ & 26.88 & - & - & $\begin{array}{c}\text { Crassostrea } \\
\text { gigas }\end{array}$ & 20 & $\begin{array}{c}\text { Juvenile } \\
\text { and } \\
\text { adult }\end{array}$ & Bougrier et al. (1995) \\
\hline
\end{tabular}


Juvenile oyster mortality influence on fluxes

\begin{tabular}{|c|c|c|c|c|c|c|c|}
\hline $0.851 \mathrm{mgO}_{2} \cdot \mathrm{gDW}^{-1} \cdot \mathrm{h}^{-1}$ & 26.59 & - & - & $\begin{array}{l}\text { Crassostrea } \\
\text { gigas }\end{array}$ & 20 & $\begin{array}{l}\text { Juvenile } \\
\text { and } \\
\text { adult }\end{array}$ & Bougrier et al. (1995) \\
\hline $1.077 \mathrm{mgO}_{2} \cdot \mathrm{gDW}^{-1} \cdot \mathrm{h}^{-1}$ & 33.66 & - & - & $\begin{array}{l}\text { Crassostrea } \\
\text { gigas }\end{array}$ & 20 & $\begin{array}{l}\text { Juvenile } \\
\text { and } \\
\text { adult }\end{array}$ & Bougrier et al. (1995) \\
\hline $0.71 \mu \mathrm{l} \mathrm{O}_{2} \cdot \mathrm{gDW}^{-1} \cdot \mathrm{h}^{-1}$ & 31.70 & - & - & $\begin{array}{l}\text { Crassostrea } \\
\text { gigas }\end{array}$ & 20 & Spat & Goulletquer et al. (1999) \\
\hline $0,53 \mu \mathrm{l} \mathrm{O}_{2} \cdot \mathrm{gDW}^{-1} \cdot \mathrm{h}^{-1}$ & 23.66 & - & - & $\begin{array}{l}\text { Crassostrea } \\
\text { gigas }\end{array}$ & & Spat & Goulletquer et al. (1999) \\
\hline $\mathrm{C}: 0,98 \underset{{ }^{1} \cdot \mathrm{h}^{-1}}{\mu \mathrm{molO}_{2} \cdot \mathrm{gDW}^{-}}$ & 21.94 & C: $0.049 \mu \mathrm{molNH}_{4} \cdot \mathrm{h}^{-1}$. ind $^{-1}$ & 0.50 & $\begin{array}{c}\text { Crassostrea } \\
\text { gigas }\end{array}$ & & Spat & This study \\
\hline $\mathrm{L}: 0,71 \underset{{ }^{1} \cdot \mathrm{h}^{-1}}{\mu \mathrm{molO}_{2} \cdot \mathrm{gDW}^{-}}$ & 15.89 & $\mathrm{~L}: 0.032 \mu \mathrm{molNH}_{4} \cdot \mathrm{h}^{-1} . \mathrm{ind}^{-1}$ & 0.33 & $\begin{array}{l}\text { Crassostrea } \\
\text { gigas }\end{array}$ & 20.8 & Spat & This study \\
\hline- & - & - & 0.84 & $\begin{array}{c}\text { Crassostrea } \\
\text { gigas }\end{array}$ & 22 & Adult & Buzin et al. (2015) \\
\hline \multirow[t]{2}{*}{ - } & - & - & 0.48 & $\begin{array}{l}\text { Crassostrea } \\
\text { gigas }\end{array}$ & 16 & Adult & Buzin et al. (2015) \\
\hline & & & 0.23 & $\begin{array}{l}\text { Crassostrea } \\
\text { gigas }\end{array}$ & 13 & Adult & Buzin et al. (2015) \\
\hline
\end{tabular}

(Dame 1972, Newell 1985, Bernard and Noakes 1990, Gale et al. 1991, Bougrier et al. 1995, Soletchnik et al. 1997, Goulletquer et al. 1999, Wan-soo et al.

2002, Buzin et al. 2015) 
Juvenile oyster mortality influence on fluxes

Table 5: Non exhaustive review of changes induced by pathogen infections on filtration, respiration and excretion rates in marine bivalves, nd: no data, NS: no significant variation, significant $\nearrow$ increase or $\searrow$ decrease

\begin{tabular}{|c|c|c|c|c|c|c|}
\hline Host & Pathogen & & Filtration/clearance rate & Respiration & Excretion & References \\
\hline Crassostrea virginica & Perkinsus marinus & protozoan & nd & NS & nd & Willson et al. (2000 \\
\hline Crassostrea virginica & haplosporidium nelsoni & protozoan & $\searrow$ & NS & nd & Newell (1985) \\
\hline Crassostrea virginica & Boonea impressa & gastropod & NS & NS & NS & Gale et al. (1991) \\
\hline Mytillus galloprovincialis & Martellia sp. & protozoan & $\nearrow$ & NS & NS & Anestis et al. (2010) \\
\hline Crassostrea gigas & Chlamydia & bacteria & $\nearrow$ & $\searrow$ & nd & Soletchnik et al. (1998) \\
\hline Ruditapes philippinarum & Vibrio tapetis & bacteria & $\searrow$ & $\searrow$ & nd & Flye-Sainte-Marie et al. (2007) \\
\hline
\end{tabular}

(Newell 1985, Gale et al. 1991, Soletchnik et al. 1998, Willson and Burnett 2000, Flye-Sainte-Marie et al. 2007, Anestis et al. 2010) 
Juvenile oyster mortality influence on fluxes

Table 6: Individual fluxes $\left(\mathrm{O}_{2}\right.$ consumption, $\mathrm{NH}_{4}$ and $\mathrm{PO}_{4}$ fluxes $)$ extrapolated to lantern scale, considering measured individual rates, lantern stocking density

(7 storeys $\times 350$ ind.storey ${ }^{-1}=2450$ individuals) and lantern density $\left(1 . \mathrm{m}^{-2}\right)$, before and during mortality events (if 30,50 or $100 \%$ cumulative mortality rates were recorded). $\mathrm{N} / \mathrm{P}$ indicates the ratio between $\mathrm{NH}_{4}$ and $\mathrm{PO}_{4}$ releases.

\begin{tabular}{|c|c|c|c|c|}
\hline & Before & $\begin{array}{c}\text { Mortality } \\
(\mathbf{3 0 \%})\end{array}$ & $\begin{array}{c}\text { Mortality } \\
(\mathbf{5 0 \%})\end{array}$ & $\begin{array}{c}\text { Mortality } \\
(\mathbf{1 0 0 \%})\end{array}$ \\
\hline Oxygen consumption $\left(\mu \mathrm{mol} . l a n t e r n^{-1} \cdot \mathrm{m}^{-2}\right)$ & 2409.5 & 1619.0 & 1549.8 & 1342.2 \\
\hline $\mathrm{NH}_{4}$ releases $\left(\mu \mathrm{mol} . l a n t e r n^{-1} \cdot \mathrm{m}^{-2}\right)$ & 119.9 & 269.9 & 365.0 & 550.4 \\
\hline $\mathrm{PO}_{4}$ releases $\left(\mu \mathrm{mol} . l a n t e r n^{-1} \cdot \mathrm{m}^{-2}\right)$ & 2.6 & 21.6 & 30.9 & 58.7 \\
\hline N/P fluxes & 46 & 12 & 12 & 11 \\
\hline
\end{tabular}

